\title{
Zmiany w rozmieszczeniu i strukturze ludności łemkowskiej na terenie powiatu nowosądeckiego w latach 1900-1947
}

\author{
Anna Wilk \\ https://orcid.org/0000-0002-3019-2782 \\ Wydział Nauk o Ziemi i Gospodarki Przestrzennej, Uniwersytet Marii Curie-Skłodowskiej
}

Zarys treści: Artykuł stanowi analizę zmian zachodzących w strukturze społecznej ludności łemkowskiej od 1900 r. do wysiedleń w latach 1945-1947 na obszarze powiatu nowosądeckiego, którego południowo-wschodnie rubieże stanowiły część regionu etnograficznego Łemkowszczyzny. W tekście podjęto także próbę wyjaśnienia na podstawie badań historycznych czynników, które rzutowały na zmiany zachodzące $\mathrm{w}$ strukturze tej grupy etnicznej pod względem ilościowym, tożsamościowym oraz wyznaniowym, jak również specyfikę łemkowskich miejscowości i zachodzących w nich przemian.

Słowa kluczowe: Łemkowie, Łemkowszczyzna, przesiedlenia, wysiedlenia, akcja „Wisła”, grupa etniczna, powiat nowosądecki

\section{Wprowadzenie}

W kontekście motywowanego politycznie zniszczenia struktury społecznej Łemków poprzez powojenne wysiedlenia zmiany demograficzno-społeczne na Łemkowszczyźnie stanowią interesujące zagadnienie zarówno dla historii politycznej, jak i geografii społecznej. Badaną grupą społeczną jest ludność łemkowska (rusińska), przynależna do wschodniego kręgu kulturowego i posługująca się etnolektem wschodniosłowiańskim. Zamieszkiwała ona niegdyś część Karpat od rzeki Poprad na zachodzie po pasmo Wielkiego Działu na wschodzie, a także Ruś Szlachtowską, czyli region etnograficzny nazwany umownie Łemkowszczyznąa ${ }^{1}$. Wśród teorii będących próbą

\footnotetext{
${ }^{1}$ Region etnograficzny ludności łemkowskiej tworzył ok. 140-150-kilometrowy klin pomiędzy osadnictwem zachodniosłowiańskim od Osławy i Laborca po linię Popradu. W wyniku podziału tego obszaru po 1918 r. między Polskę
}

Abstract: The article constitutes an analysis of the changes in the social structure of the Lemko population which took place in the period between 1900 and the displacements of the years 1945-1947 in the territory of Nowy Sącz County, whose south-eastern areas formed part of the so-called Lemkivshchyna ethnographic region. The author of the paper also uses existing historical research to determine the factors which influenced the changes in the structure of the above defined ethnic group in terms of population size, identity, and religion, as well as discusses the characteristic features of Lemko settlements and their transformations.

Keywords: Lemkos, Lemkivshchyna, resettlements, displacements, Operation Vistula, ethnic group, Nowy Sącz County

i Czechosłowację jego polską część zaczęto nazywać północną Łemkowszczyzną. Na zachodzie granicę etnograficzną Łemkowszczyzny wyznaczała linia sąsiedztwa z polskimi góralami, na północnym zachodzie - z Lachami sądeckimi, od Grybowa po Sanok - z podgórską ludnością polską, a na północnym wschodzie i wschodzie - z Dolinianami i Bojkami. R. Reinfuss, Etnograficzne granice temkowszczyzny. Próba wytyczenia granicy Łemkowszczyzny na podstawie zasięgu temkowskiego stroju, „Ziemia. llustrowany miesięcznik krajoznawczy", 10/11, 1936, s. 246. Po stronie polskiej Łemkowszczyzna rozpościerała się wzdłuż grzbietu Karpat: od górnego biegu Dunajca poprzez górne dorzecze Wistoki, Ropy, Jasiołki i Wistoka po linię 0sławy i górnego Sanu. Łemkowie zamieszkiwali więc wschodnia część Karpat znajdujacychch się w obecnych granicach Polski: Beskid Sądecki ¡ Beskid Niski, aż po Bieszczady Zachodnie. S. Nabywaniec, Łemkowszczyzna w świetle badań i opinii, „Resovia Sacra. Studia Teologiczno-Filozoficzne Diecezii Rzeszowskiej”, 2, 1995, s. 85. Zob. też: M. Parczewski, Początki ksztattowania się polsko-ruskiej rubieży etnicznej w Karpatach, Kraków 1991, s. 15. W polskiej historiografii jako wschodnią granicę Łemkowszczyzny przyjmuje się przeważnie za ustaleniami Romana Reinfussa pasmo Wielkiego Działu. W ukraińskiej natomiast przesuwa się ją na linię górnego Sanu, włączając tym samym w obszar Łemkowszczyzny tereny uznawane przez polskich badaczy za bojkowskie. R. Reinfuss, Etnograficzne granice; P. Trzeszczyńska, Łemkowszczyzna zapamiętana. Opowieści o przeszłości iprzestrzeni, Kraków 2013, s. 64. Zob. też: J. Moklak, temkowszczyzna w II RP (1929 r.), skala: 1:375 000, w: J. Moklak, temkowszczyzna w Drugiej Rzeczpospolitej. Zagadnienia polityczne i wyznaniowe, Kraków 1997. 
wyjaśnienia, skąd wywodzą się przodkowie Łemków, wyłaniają się opozycyjne nurty migracyjny i autochtoniczny ${ }^{2}$. W polskiej historiografii za najbardziej prawdopodobną przyjęto hipotezę migracji wołoskiej ${ }^{3}$,

s. 224; В. Кубійович, Етнографрічна карта південнозахідньої України (Галичини), skala: 1:250 000, Вісбаден 1983; І. Ровенчак, Лемківщина, skala: 1:275 000, Львів 2002.

2 Opozycyjna wobec teorii migracji wołoskich pasterzy jest teoria autochtonizmu Łemków w Karpatach. Próbuje ona dowieść czysto ruskiej etnogenezy tej ludności, często wywodzonej od Białych Chorwatów, którzy mieli zasiedlać tereny późniejszej Łemkowszczyzny już od VII w., a w czasach późniejszych nadać sobie miano Rusinów bądź Rusinów karpackich, ze względu na silne związki z Rusią Kijowską. I. Krasowski, Problem autochtonizmu Rusinów w Beskidzie Niskim, w: Łemkowie w historii i kulturze Karpat, cz. 1, red. J. Czajkowski, Rzeszów 1992, s. 383; М. Грушевський, Історія України-Руси, т. 1, Львів 1904, s. 190; І. Зілинський, Питання про лемківсько-бойківську мовну границю, , Lud Stowiański”, 4 (1), 1938, s. 38. W ukraińskiej historiografii popularna jest teoria wywodząca Łemków wprost od Rusinów halickich. Przodkowie Łemków wyruszyli według niej z doliny Cisy między ujściami Borżawy i Tereswy, a więc z ukraińskiego Zakarpacia, i przed 1254 r. przybyli na południowe stoki Karpat, w okolice Szarysza, a wiek później przeszli na pótnocną stronę Beskidu. B. Strumiński, 0 pochodzeniu Łemków z punktu widzenia językoznawstwa, „Magury”, 91, 1992, s. 87. Brak źródeł, które jasno wyjaśniałyby pochodzenie ludności temkowskiej, nakazuje jednak ostrożność w próbie odpowiedzi na to nurtujące badaczy pytanie.

${ }^{3}$ Według wielu hipotez Wołosi mieli wyruszyć z Bałkanów: K. Dobrowolski, Migracje wołoskie na ziemiach polskich, Lwów 1930, s. 8; tenże, Dwa studia nad powstaniem kultury ludowej w Karpatach Zachodnich. Z badań nad zagadnieniem wołoskim w Karpatach Zachodnich, w: Studia Podhalańskie oraz Bibliografia pasterstwa Tatr i Podhala, oprac. W. Antoniewicz, K. Dobrowolski, W.H. Paryski, Wrocław 1970 (Pasterstwo Tatr Polskich i Podhala, 8), s. 132; M. Misiak, Łemkowie. W kręgu badań nad mniejszościami etnolingwistycznymi w Europie, Wrocław 2006, s. 49; J. Czajkowski, Studia nad Łemkowszczyzną, Sanok 1999, s. 119; tenże, Dzieje osadnictwa historycznego na Podkarpaciu i jego odzwierciedlenie w grupach etnicznych, w: Łemkowie w historii, s. 156; R. Reinfuss, Łemkowie jako grupa etnograficzna, Sanok 1998, s. 8; M. Parczewski, Geneza Łemkowszczyzny w świetle wyników badań archeologicznych, w: Łemkowie w historii, s. 22. Por. J. Nalepa, Łemkowie, Wołosi i Biali Chorwaci. Uwagi dotyczące kwestii genezy osadnictwa ruskiego na polskim Podkarpaciu, „Acta Archaeologica Carpathica”, 24, 1997-1998, s. 157. Są jednak i takie, które wywodzą ich z Wielkiej Niziny Węgierskiej i Wyżyny Ondawskiej we wschodniej Stowacji: Z. Szanter, Jeszcze o osadnictwie zza południowej granicy w Beskidzie Niskim i Sądeckim, w: Łemkowie i temkoznawstwo w Polsce, red. A.A. Zięba, Kraków 1997 (Prace Komisji Wschodnioeuropejskiej Polskiej Akademii Umiejętności, 5), s. 182. Mówi się też wreszcie o przybyciu Wołochów z terenów Mołdawii, Wołoszczyzny i Siedmiogrodu: A.A. Zięba, Wokót sporów o etnogenezę Łemków, w: Łemkowie, red. B. Machul-Telus, Warszawa 2013, s. 16; R. Reinfuss, Łemkowie, s. 117; A. Fastnacht, Osadnictwo ziemi sanockiej w latach 1340-1650, Wroctaw 1962, s. 210; M. Parczewski, Geneza, s. 22. Część badaczy kwestionuje jednak etniczny charakter tych społeczności, widząc w nich wyspecjalizowaną pasterską grupę zawodową: Czt. K. Dobrowolski przedstawit własną prace pt. „Zderzenie kultury rolniczej z pasterską”, „Sprawozdania z Czynności i Posiedzeń PAU”, 5, 1939, s. 191-194; G. Jawor, Osady prawa wołoskiego i ich mieszkańcy na Rusi Czerwonej w późnym średniowieczu, Lublin 2004, s. 34; K. Dobrowolski, Etniczny aspekt osadnictwa wołoskiego na przedpolu Karpatw Małopolsce ina Rusi Czerwonej (XIV-XV), w: Początki która od ok. XIV w. napływała łukiem Karpat ze wschodu na zachód ${ }^{4}$, poszukując nowych obszarów hodowlano-pasterskich i stopniowo ulegając rutenizacji w wyniku mieszania się z prowadzącymi osiadły tryb życia Rusinami ${ }^{5}$.

Podstawowym kryterium odrębności etnicznej Łemków były: religia (prawosławie, a od przełomu XVII i XVIII w. grekokatolicyzm), etnolekt oraz nazwa etniczna Rusin ${ }^{6}$. Ludność ta zajmowała się przeważnie rolnictwem i hodowlą zwierząt. Nieliczną inteligencję stanowili wśród niej duchowni, lekarze i prawnicy. W 1931 r. na terenie RP mieszkało ok. 130 tys. Łemków, w tym ok. 25 tys. na południowo-wschodnich rubieżach powiatu nowosądeckiego ${ }^{7}$. Od drugiej połowy XIX w. społeczność ta znajdowała się pod wpływem trzech ugrupowań narodowych: staroruskiego, prorosyjskiego oraz ukraińskiego, co prowadziło do podziałów wewnętrznych. Do dezintegracji grupy przyczyniła się jednak w głównej mierze polityka państwa polskiego, które w latach 1945-1946 objęło ją akcją przesiedleńczą do Ukraińskiej Socjalistycznej Republiki Radzieckiej (dalej: USRR), a w 1947 - akcją „Wisła”, doprowadzając do całkowitej zmiany jej struktury społecznej.

sąsiedztwa. Pogranicze polsko-rusko-stowackie w średniowieczu. Materiaty z konferencii, red. M. Parczewski, Rzeszów 1996, s. 301.

${ }^{4}$ Początek kolonizacji wołoskiej na terenie Łemkowszczyzny szacowany jest przez badaczy na drugą połowę XIV lub XV stulecie: K. Dobrowolski, Migracje, s. 9; M. Parczewski, Geneza, s. 20; Doc. Z. Stieber przedstawia swoją prace pt. „Wptyw polski i stowacki na gwary temków”, ,Sprawozdania z Czynności i Posiedzeń PAU”, 41 (2), 1936, s. 45. Zakończenie procesu zasiedlania północnych i południowych stoków Karpat przez ludy pasterskie miało przypadać na XVI-XVII w. M. Parczewski, Geneza, s. 20; J. Czajkowski, Dzieje, s. 161.

${ }^{5}$ Zob. A. Stadnicki, 0 wsiach tzw. wołoskich na pótnocnym stoku Karpat, Lwów 1848; A. Fastnacht, Osadnictwo; J. Czajkowski, Dzieje; K. Pieradzka, Na szlakach Łemkowszczyzny, Kraków 1939; E. Długopolski, Przyczynek do osadnictwa wołoskiego w Karpatach, Kraków 1916; K. Dobrowolski, Migracje; H. Duć-Fajer, Literatura temkowska w drugiej połowie XIX i na początku XX wieku, Kraków 2001, s. 8-9.

${ }^{6}$ E. Michna, Łemkowie, grupa etniczna czy naród?, Kraków 1995, s. 33

7 A. Wilk, Łemkowie. Między integracją a rozproszeniem 1918-1989, Warszawa 2019. Por. E. Michna, Łemkowie, s. 5; S. Dubiel-Dmytryszyn, Łemkowie a ruch rusiński, „Rocznik Ruskiej Bursy”, 2007, s. 135; tenże, Rusini - Łemkowie - Ukraińcy. W kręgu Rusińskiej tożsamości etnicznej w Karpatach, Krosno 2018. 


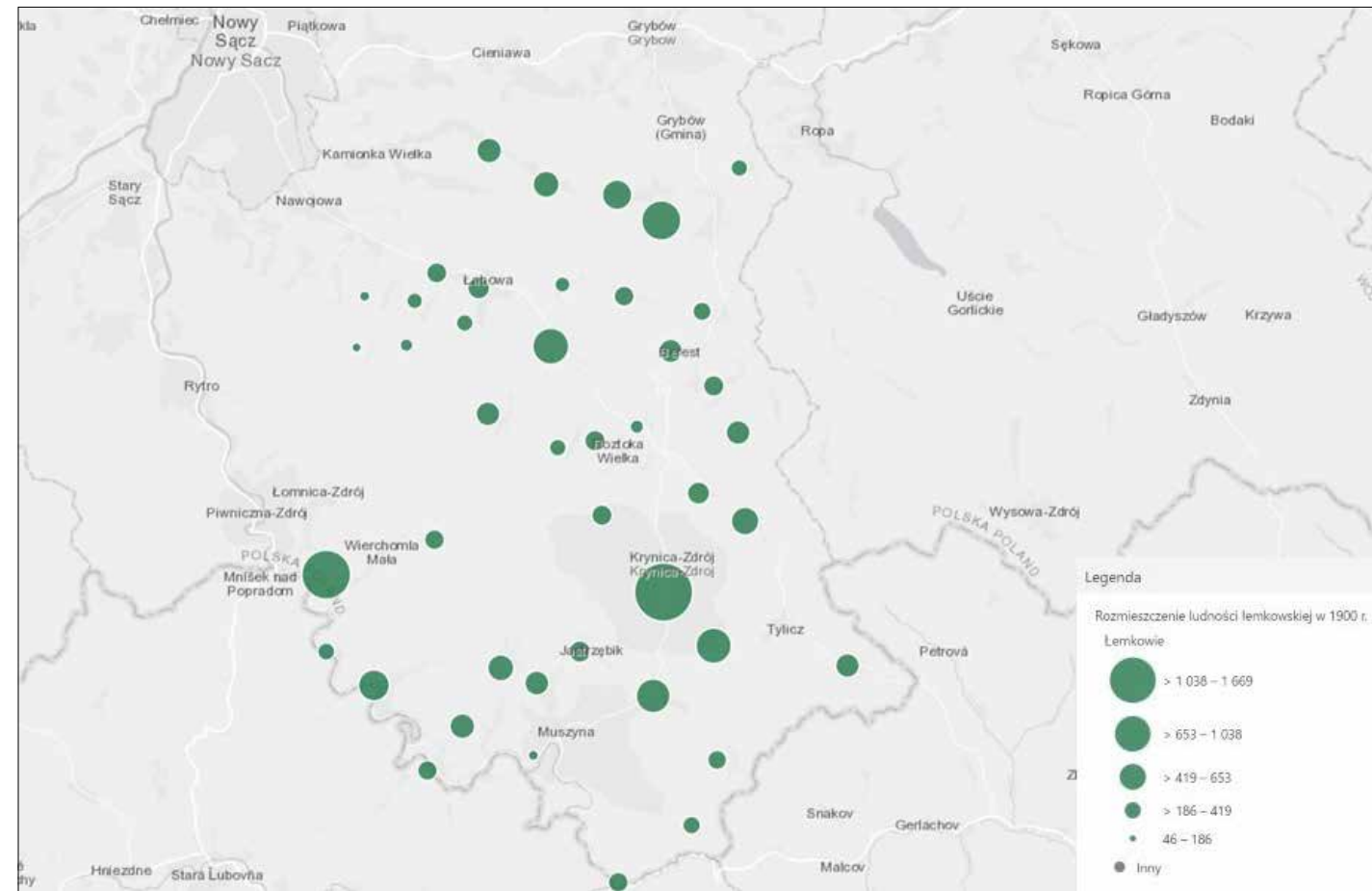

Ryc. 1. Rozmieszczenie ludności temkowskiej na terenie powiatu nowosądeckiego w $1900 \mathrm{r}$.

Źródto: oprac. własne na podstawie: „Gemeindelexikon der im Reichsrate vertretenen Königreiche und Länder”, Bd. 12: „Galizien”, Wien 1907

Celem niniejszego artykułu jest wstępna analiza zmiany liczby ludności łemkowskiej na terenie powiatu nowosądeckiego w latach 1900-1947. Badania podzielone zostały na dwa etapy. Pierwszy dotyczy zmiany struktury społeczności łemkowskiej w latach 1900-1931, z uwzględnieniem zróżnicowania ludności pod względem językowym i wyznaniowym, a także miejscowości pod względem etniczno-narodowym i wyznaniowym. Przedstawiono tu zmiany liczby grekokatolików w powiecie nowosądeckim w latach 1900-1931 i omówiono zjawisko konwersji na prawosławie. Zróżnicowanie wyznaniowe zamieszkanych przez Łemków miejscowości przedstawione zostało w formie wykresów. Drugim etapem badań była próba ustalenia liczby ludności łemkowskiej w 1945 r., przed objęciem jej akcją przesiedleńczą na teren USRR, a także przedstawienie wywózek z lat 1945-1947, tj. procesu dezintegracji struktury społecznej Łemków. Szczegółowe dane ilościowe dotyczące omawianych miejscowości zaprezentowane zostały w tabelach. Uzupełnieniem analizy zmian liczebności omawianej grupy w latach 1900-1947 jest przedstawienie ich politycznych przyczyn. Artykuł ma charakter przyczynkarski i stanowi pierwszy etap badań nad zmianą struktury społecznej zachodniej Łemkowszczyzny.

Badany obszar obejmuje 44 zamieszkiwane przez ludność łemkowską miejscowości powiatu nowosądeckiego w granicach z 1932 r., kiedy ponownie włączono w jego obręb część zniesionego powiatu grybowskiego (utworzonego w 1867 r.) ${ }^{8}$.

\footnotetext{
${ }^{8}$ Objęte badaniami miejscowości to: Andrzejówka, Baranowiec, Berest, Binczarowa, Bogusza, Czaczów, Czyrna, Dubne, Florynka, Jastrzębik, Kamianna Kotów, Królowa Ruska, Krynica, Krynica-Wieś, Krzyźówka, Leluchów, Łabowa, Łabowiec, Łosie, Maciejowa, Milik, Mochnaczka Niżna, Mochnaczka Wyżna, Muszyna, Muszynka, Nowa Wieś, Piorunka, Polany, Powroźnik, Roztoka Mała, Roztoka Wielka, Składziste, Stotwiny, Szczawnik, Tylicz, Uhryń, Wawrzka, Wierchomla Mała, Wierchomla Wielka, Wojkowa, Ztockie, Zubrzyk, Żegiestów.
} 
Analizie krytycznej poddane zostały dokumenty z Archiwum Narodowego w Krakowie, Archiwum Narodowego w Krakowie Oddziału w Nowym Sączu, Archiwum Instytutu Pamięci Narodowej w Warszawie, Archiwum Instytutu Pamięci Narodowej w Krakowie, a także Archiwum Akt Nowych w Warszawie. Istotny materiał źródłowy stanowią również dokumenty wydane, zwłaszcza spisy ludności z lat 1900 i 1921, które przynoszą szczegółowe informacje odnośnie do poszczególnych miejscowości.

\section{Zmiany w strukturze ludności łemkowskiej w latach 1900-1931}

Łemkowie zamieszkiwali południowo-wschodnie rubieże powiatu nowosądeckiego. Według ustaleń Romana Reinfussa północną granicę Łemkowszczyzny wyznaczały na tym obszarze miejscowości: Wierchomla Wielka, Roztoka Mała (ob. nie istnieje), Składziste, Maciejowa, Łabowa, Bogusza, Królowa Ruska (ob. Królowa Górna), Binczarowa, Florynka i Wawrzka?. Ludność łemkowska budowała swoją odrębność poprzez językowo-kulturową izolację od Polaków, a stosunki między obiema społecznościami miały przede wszystkim charakter handlowy i administracyjny. $\mathrm{Na}$ rozwój grupowego izolacjonizmu Łemków wpływały również górski i pograniczny charakter Łemkowszczyzny ${ }^{10}$, a także rzadkość występowania polsko-łemkowskich wsi. Miejscowości łemkowskie charakteryzowały się znikomą różnorodnością etniczną i wyznaniową: zamieszkane były głównie przez Łemków, z nieliczną ludnością żydowską i niewielkim odsetkiem Polaków $^{11}$. W 1900 r. ok. 20 proc. łemkowskich miejscowości na terenie

\footnotetext{
${ }_{9}^{9}$ R. Reinfuss, Etnograficzne granice, s. 246.

${ }^{10}$ H. Duć-Fajfer, Literatura, s. 10; E. Michna, Kwestie etniczno-narodowościowe na pograniczu Stowiańszczyzny Wschodniej i Zachodniej. Ruch rusiński na Stowacji, Ukrainie i w Polsce, Kraków 2004, s. 55. Zob. też: B. Horbal, Dziatalność polityczna Łemków na Łemkowszczyźnie 1918-1921, Wroctaw 1997, s. 8; R. Reinfuss, Etnograficzne granice, s. 241.

${ }^{11}$ Gemeindelexikon der im Reichsrate vertretenen Königreiche und Länder, Bd. 12: Galizien, Wien 1907.
}

Sądecczyzny było jednolite etniczne (100 proc. mieszkańców stanowili Łemkowie). Były to w głównej mierze osady liczące mniej niż 550 mieszkańców, np. Łosie (292), Wierchomla Mała (394), Polany (349), Łabowiec (293), Roztoka Mała (159), Składziste (263) czy Uhryń (527). W 57 proc. łemkowskich wsi Łemkowie stanowili 95-99 proc. mieszkańców. Największa z nich, Wierchomla Wielka, liczyła 1401 osób, w tym 1359 Łemków. Poniżej 70 proc. populacji grupa ta stanowiła w jedynie 7 proc. zamieszkanych przez siebie wsi. Dotyczyło to przede wszystkim większych miejscowości, np. Krynicy-Wsi, gdzie spośród 2382 mieszkańców 1621 (68 proc.) deklarowało w spisie narodowość rusińską (ryc. 1). Niewielkie zróżnicowanie etniczne miejscowości utrzymywało się na łemkowsko-polskim pograniczu pomimo występowania nielicznych wsi mieszanych, które kreśliły na wielu odcinkach wyraźną granicę między osadnictwem obu grup (pogranicze stykowe). W wybranych sądeckich miejscowościach na granicy Łemkowszczyzny odsetek ludności łemkowskiej prezentował się w 1900 r. następująco: Wierchomla Wielka - 97 proc., Roztoka Mała - 100 proc., Składziste - 99,5 proc., Maciejowa - 95 proc., Łabowa - 69 proc., Bogusza - 98,4 proc., Królowa Ruska 82 proc., Binczarowa - 98 proc., Florynka -94 proc., Wawrzka - 93 proc. ${ }^{12}$ Warto też zwrócić uwagę na fakt, że społeczność ta mieszkała głównie na terenach wiejskich. Nie było więc łemkowskich miast, a nieliczne większe ośrodki - m.in. Nowy Sącz, Muszynę, Krynicę-Zdrój, Tylicz oraz Żegiestów - w większości zamieszkiwała ludność polska.

$\mathrm{Na}$ rozwój tożsamości Łemków rzutowała działalność stronnictw narodowych z Galicji Wschodniej, reprezentujących różne koncepcje przynależności narodowej Rusinów, w tym łemkowskiej. Pod koniec XIX w. za sprawą wykształconej

12 Tamże. 


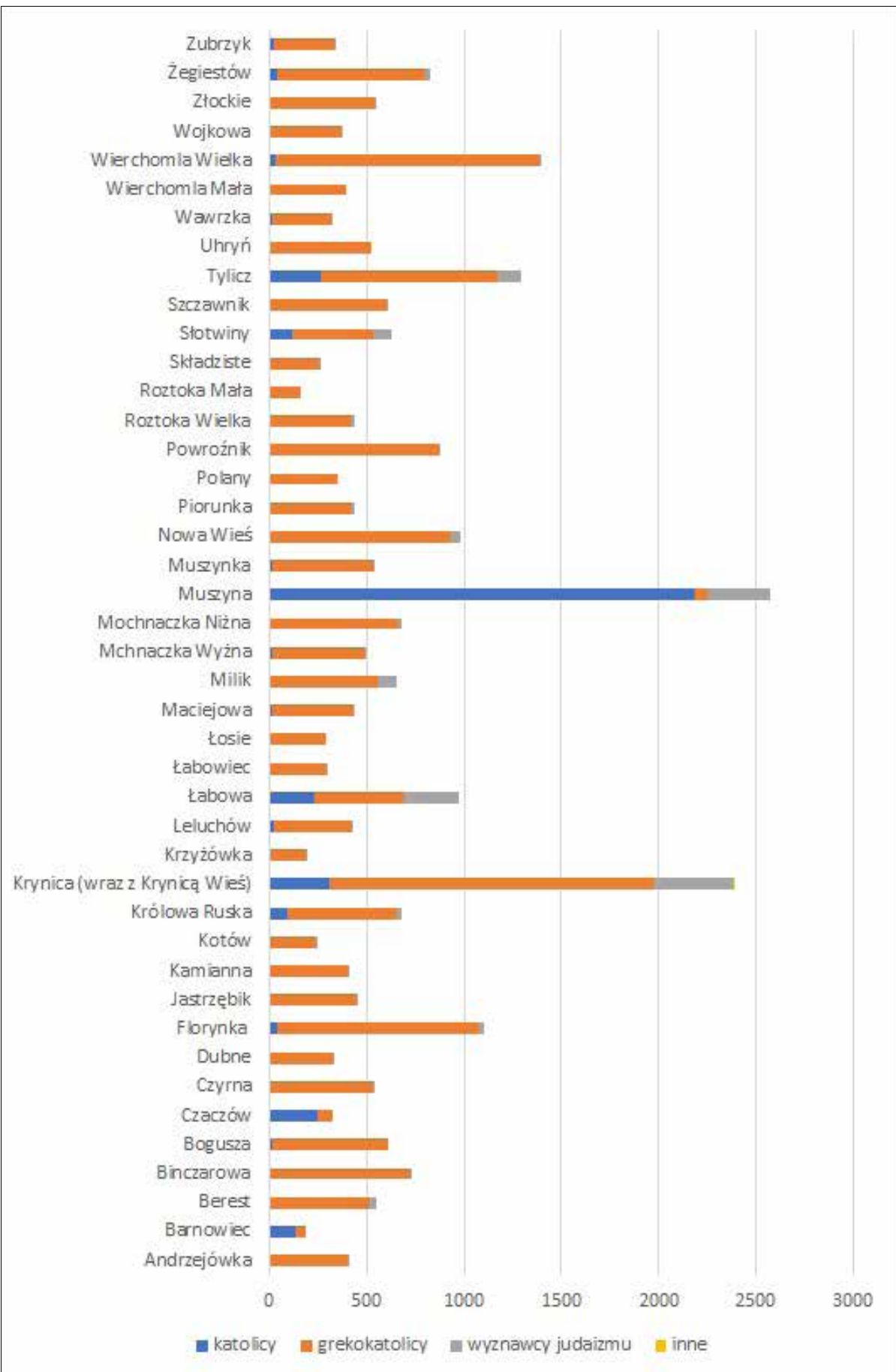

Ryc. 2a. Zróżnicowanie religijne zamieszkiwanych przez Łemków miejscowości powiatu nowosądeckiego w $1900 \mathrm{r}$. Żródto: oprac. własne na podstawie: „Gemeindelexikon”; „Skorowidz miejscowości Rzeczypospolitej Polskiej opracowany na podstawie wyników Pierwszego Powszechnego Spisu Ludności z dn. 30 września 1921 r. i innych źródef urzędowych”, t. 12: „Województwo krakowskie. Śląsk Cieszyński”, Warszawa 1925 


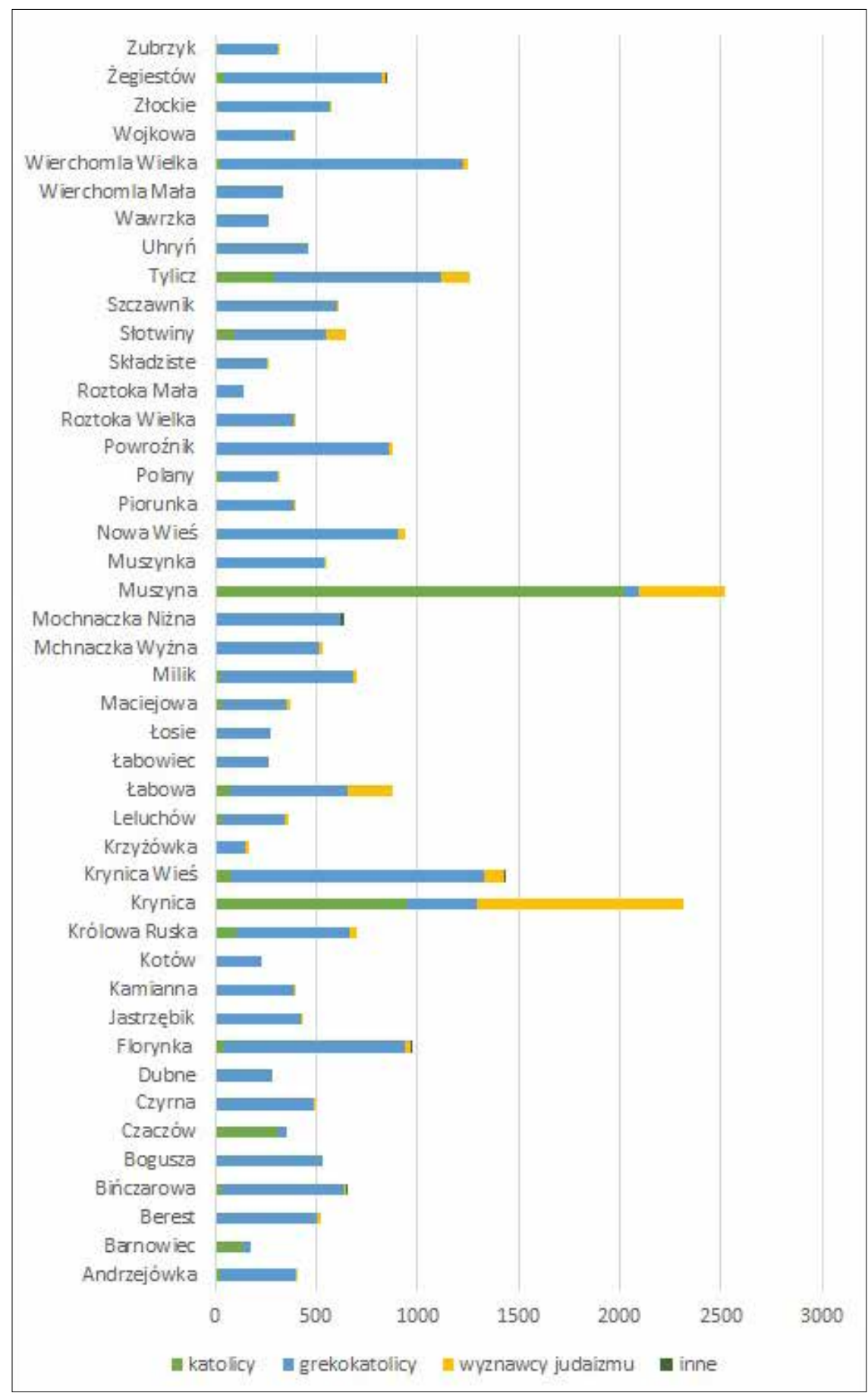

Ryc. 2b. Zróżnicowanie religijne zamieszkiwanych przez Łemków miejscowości powiatu nowosądeckiego w $1921 \mathrm{r}$.

Żródto: oprac. własne na podstawie: „Gemeindelexikon”; „Skorowidz miejscowości” 
we Lwowie inteligencji głoszone przez nie hasła stopniowo docierały na Łemkowszczyznę ${ }^{13}$. Rusofile przekonywali o rosyjskiej przynależności narodowej, starorusini postulowali uznanie Rusinów za naród odrębny od ukraińskiego i rosyjskiego, a Ukraińcy walczyli o rozwój własnego ruchu narodowego, dążącego do uświadomienia Łemkom, że przynależą do narodu ukraińskiego. Ruchy staroruski i rusofilski stanęły w opozycji wobec ukraińskiego, a rosnąca między nimi rywalizacja doprowadziła do walki o sympatię Łemków. Strefy wpływów poszczególnych ugrupowań narodowych ukształtowały się tu w okresie międzywojennym: na zachodniej Łemkowszczyźnie przeważały orientacje prorosyjska i staroruska, na wschodniej zaś - ukraińska ${ }^{14}$. Działalność wymienionych stronnictw - m.in. za pomocą literatury, szkolnictwa i wydarzeń kulturalnych, ale również z wykorzystaniem aspektu wyznaniowego - prowadziła do rozwoju różnych tożsamości narodowych w obrębie jednej grupy etnicznej.

W latach 1900-1921 widoczny jest spadek liczby ludności łemkowskiej zamieszkującej Sądecczyznę. W spisie Gemeindelexikon der im Reichsrate vertretenen Königreiche und Länder z 1900 r. odnotowano 21661 grekokatolików i 21890 osób deklarujących narodowość rusińską. W 1921 r. na Sądecczyźnie mieszkało natomiast 20629 osób wyznania greckokatolickiego (ryc. 2), a narodowość rusińską zadeklarowało w spisie 18 897. W stosunku do 1900 r. odnotowano spadek liczby grekokatolików o 5 proc. (ryc. 3), a o 14 proc. zmniejszyła się liczba osób deklarujących narodowość rusińską. Ogólna populacja zmniejszyła się w tym czasie w 83 proc. badanych miejscowości ${ }^{15}$. Znaczny spadek liczby Łemków odnotowano zwłaszcza w miejscowościach, w których było ich

\footnotetext{
13 Zob. J. Moklak, Łemkowszczyzna.

${ }^{14}$ E. Michna, Kwestie, s. 16; H. Duć-Fajfer, Literatura, s. 21; B. Horbal, Dziatalność, s. 29; M. Misiak, W kręgu, s. 36; J. Moklak, temkowszczyzna, s. 18.

${ }^{15}$ Gemeindelexikon.
}

mniej niż 30 proc. W Baranowcu, gdzie w 1900 r. społeczność łemkowska stanowiła 25 proc. ogółu mieszkańców, w 1921 r. żaden z 33 grekokatolików nie zadeklarował w spisie narodowości rusińskiej. Podobnie było w przypadku Czaczowa, gdzie w 1900 r. Łemkowie stanowili 16 proc. mieszkańców, a w 1921 r. żaden z 39 o wyznaniu greckokatolickim nie zadeklarował narodowości rusińskiej ${ }^{16}$. Mimo że w obu spisach występuje pytanie o narodowość, najbardziej wiarygodną kategorią, która pozwala analizować zmiany liczby ludności łemkowskiej, jest wyznanie greckokatolic$\mathrm{kie}^{17}$. Właśnie tym kryterium kierowała się administracja państwowa $\mathrm{w}$ pierwszej połowie XX w.

Na spadek liczby Łemków wpłynęły zarówno pierwsza wojna światowa, jak i powojenna emigracja zarobkowa do Ameryki Północnej. Wyjazdy za ocean były szczególnie popularne w pierwszych latach po wojnie, kiedy Łemkowie znajdowali się w ciężkiej sytuacji materialnej, potęgowanej zacofaniem gospodarczym obszarów górskich ${ }^{18}$.

W latach 1921-1931 nastąpił wzrost liczby ludności łemkowskiej o ok. 18 proc. (ryc. 4). W 1931 r. język ruski jako ojczysty wskazało 23666 osób, ukraiński natomiast - 586 (część z nich z pewnością stanowiła migrująca na Łemkowszczyznę ukraińska inteligencja). Łemkowie stanowili wówczas ok. 15 proc. wszystkich mieszkańców powiatu nowosądeckiego i ok. 20 proc. populacji wsi. Przewaga ludności polskiej w powiecie musiała wpływać

\footnotetext{
${ }^{16}$ Skorowidz miejscowości Rzeczypospolitej Polskiej opracowany na podstawie wyników Pierwszego Powszechnego Spisu Ludności z dn. 30 września 1921 r. iinnych žródeł urzędowych, t. 12: Województwo krakowskie. Śląsk Cieszyński, Warszawa 1925

17 Zob. J. Tomaszewski, Z. Landau, Społeczeństwo Drugiej Rzeczpospolitej (uwagi polemiczne), „Przegląd Historyczny”, 61 (2), 1970.

${ }^{18}$ Archiwum Narodowe w Krakowie [dalej: ANK], Komenda Wojewódzka Policji Państwowej w Krakowie, 133, Sprawozdanie z lutego 1923 r., k. 503; tamże, Starostwo Powiatowe w Grybowie, II, 45, Sprawy wojskowe: wypełnianie obowiązku wojskowego przez Rusinów z terenu powiatu 1921-1923, b.p. Zob. tez: M. Soja, Zmiany zaludnienia temkowszczyzny w latach 1869-1998, w: Człowiek i przestrzeń. Profesorowi Adamowi Jelonkowi w 70. rocznicę urodzin, red. B. Kortus, Kraków 2001.
} 


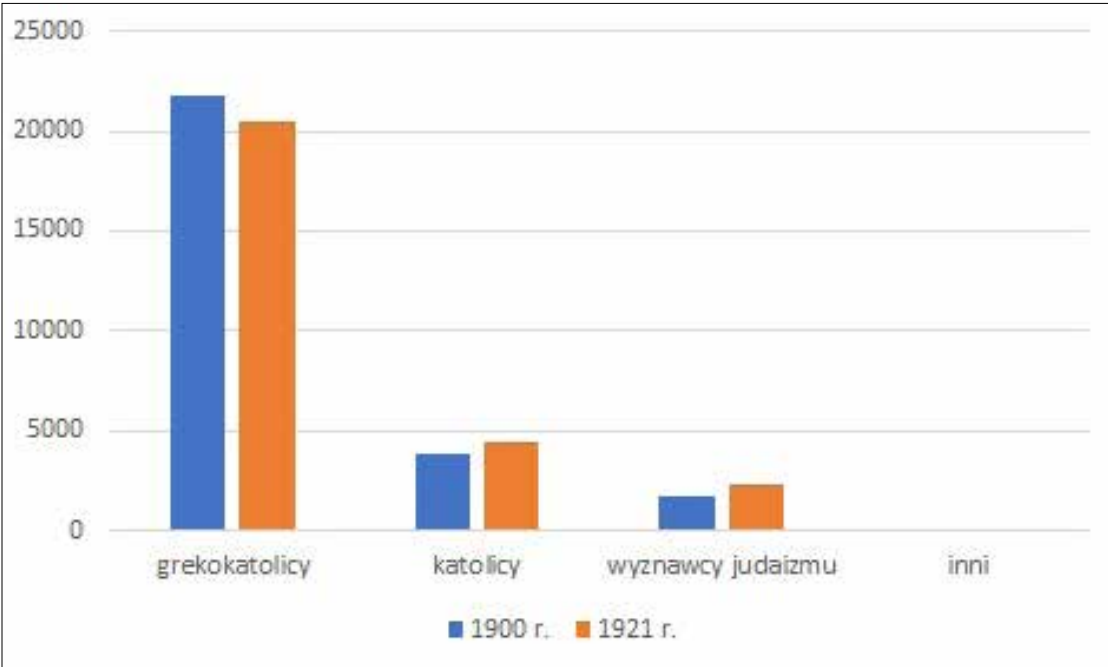

Ryc. 3. Zróżnicowanie religijne zamieszkanych przez Łemków miejscowości powiatu nowosądeckiego w latach 1900 i 1921.

Źródło: oprac. własne na podstawie: „Gemeindelexikon”; „Skorowidz miejscowości”

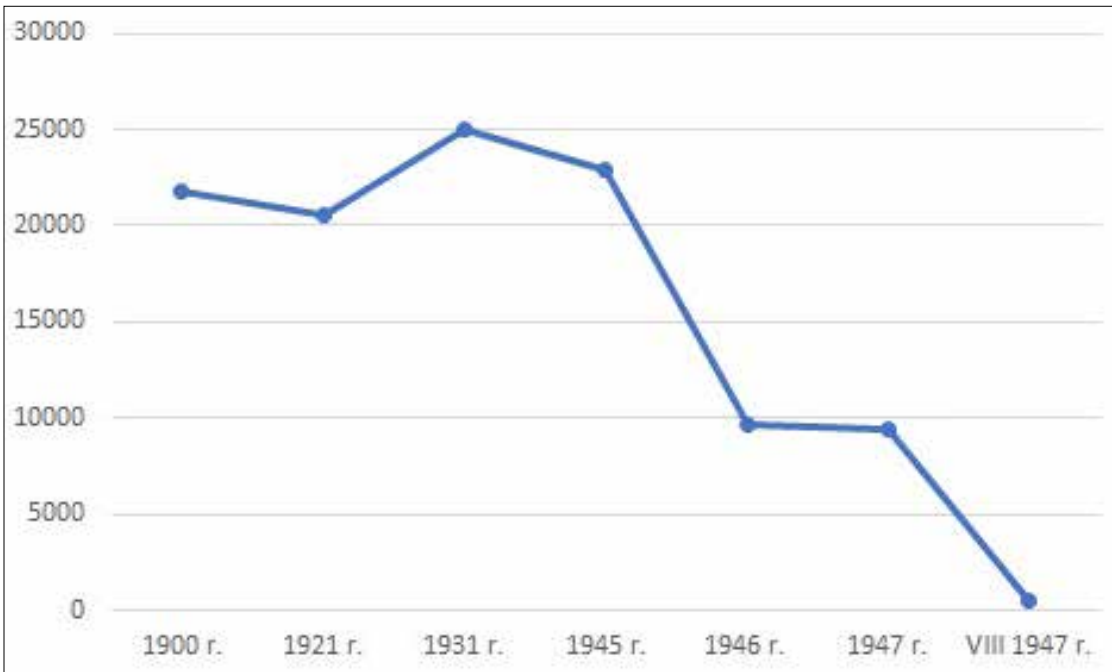

Ryc. 4. Zmiany liczby ludności łemkowskiej na terenie powiatu nowosądeckiego w latach 1900-1947. Żródto: oprac. własne na podstawie: „Gemeindelexikon”; „Skorowidz miejscowości”; „Drugi powszechny spis ludności”, s. 26-34; „Protokót końcowy przesiedlenia Ukraińców z powiatu nowosądeckiego do USSR”, w: „Repatriacja czy deportacja. Przesiedlenie Ukraińców z Polski do USRR. Dokumenty”, t. 2, red. E. Misito, Warszawa 1999, dok. 74, s. 152; AAN, 527, Rejonowy Przedstawiciel RP do Spraw Ewakuacji w Nowym Sączu 1191/5, Sprawozdania z przebiegu ewakuacji ludności ukraińskiej i innej do USRR, stan na dzień 31 grudnia 1945 r., k. 13; tamże, Sprawozdanie z przebiegu ewakuacji ludności ukraińskiej i innej do USRR, stan na dzień 31 maja 1946 r., k. 16; Archiwum Narodowe w Krakowie Oddział w Nowym Sączu [dalej: ANNS], PUR, 113/31/47, Imienny wykaz przesiedlonej ludności temkowskiej z powiatu Nowy Sącz; Archiwum Instytutu Pamięci Narodowej w Warszawie [dalej: AIPN], MSW, 00231/92, t. 81, Wykaz ilościowy ludności wysiedlonej i pozostawionej na miejscu w pow. Nowy Sącz w okresie od 30 czerwca - 4 lipca 1947 r., k. 197-210; tamże, Zestawienie ludności i sprzętu z powiatu Nowy Sącz w okresie od 5 do 9 lipca 1947 r., k. 196 
na społeczność łemkowską, zarówno jeśli chodzi o utrzymywanie izolacjonizmu grupowego, jak i przejmowanie (mimo podziału świata na swój i obcy) wzorców kulturowych, które wpływały na wyjątkowość tej grupy. Warto zwrócić uwagę, że w spisie z 1931 r. pytanie o narodowość zastąpione zostało pytaniem o język ojczysty ${ }^{19}$. Budziło to wiele kontrowersji, gdyż język nie zawsze świadczył o tożsamości narodowej jego użytkownika ${ }^{20}$.

Wyniki spisu z 1931 r. obnażyły, jak niewielkim poparciem cieszyła się na zachodniej Łemkowszczyźnie orientacja proukraińska. Zdecydowanie zwyciężyły tu regionalizm oraz szeroko rozumiana ruskość, co z jednej strony można interpretować jako powodzenie opcji staroruskiej, a z drugiej - jako brak większej krystalizacji tożsamości narodowej i stronienie od spraw politycznych ${ }^{21}$. W dwudziestoleciu międzywojennym widoczne jest zdecydowane odbicie i wyraźny przyrost liczby Łemków. Według szacunków Wołodymyra Kubijowycza w 1939 r. populacja tej grupy w powiecie nowosądeckim liczyła 27270 osób $^{22}$.

Spis ukazał także zmianę, jaka zaszła w strukturze wyznaniowej Łemków. W 1931 r. w powiecie nowosądeckim odnotowano 21413 grekokatolików (wzrost o 12 proc.) oraz 3647 wyznawców prawosławia, z czego większość stanowili konwertyci z grekokatolicyzmu. Wzrost liczby prawosławnych wynikał z misyjnej działalności Cerkwi prawosławnej, ale był też rezultatem konfliktu wyznaniowego

\footnotetext{
${ }^{19}$ Drugi powszechny spis ludnościz dn. 9 XII 1931 r. Mieszkania i gospodarstwa domowe. Ludność. Stosunki zawodowe. Województwo Krakowskie bez miasta Krakowa, red. E. Szturm de Sztrem i in., Warszawa 1938 (Statystyka Polski. Seria C, 88), s. 26-34.

${ }^{20}$ Zbigniew Landau i Jerzy Tomaszewski uznali, że w województwach południowo-wschodniej Polski doszto do fałszowania wyników spisu na korzyść Polaków. Wskazali, że odnośnie do mniejszości narodowych najbardziej wiarygodne są w nim dane dotyczące liczby wiernych poszczególnych wyznań. J. Tomaszewski, Z. Landau, Społeczeństwo, s. 316.

${ }^{21}$ A. Wilk, temkowie, s. 120

22 В. Кубійович, Етнічні групи південносхідньої України (Галичини) на 1.1.1939, Вісбаден 1983 (http://diasporiana.org.ua/wp-content/ uploads/books/10893/file.pdf, dostęp: 18 września 2020).
}

toczonego wówczas na Łemkowszczyźnie w wyniku niezgody na ukrainizację Łemków prowadzoną przez greckokatolickich duchownych ze Lwowa. Spór ten doprowadził do licznych konwersji na prawosławie we wsiach zachodniej Łemkowszczyzny, a ich symbolem stał się wiec w Tylawie koło Krosna, gdzie ludność opowiedziała się za zmianą wyznania greckokatolickiego. W 1927 r. zrobili to praktycznie wszyscy mieszkańcy gmin Królowa $\mathrm{Ru}$ ska i Bogusza - łącznie 1226 osób; konwersji dokonała także wieś Binczarowa ${ }^{23}$. We wrześniu 1928 r. konwersji dokonali mieszkańcy Bartnego, Męcina, Wapiennego oraz Kotania ${ }^{24}$. W Boguszy natomiast powołana została etatowa filia parafii dla miejscowości Bogusza i Królowa Ruska ${ }^{25}$. Podnoszona niekiedy w historiografii kwestia rodzącej się w tym okresie potrzeby samookreślenia Łemków, która miała się przejawiać zmianą wyznania ${ }^{26}$, nie wyjaśnia wszystkich zawiłości sytuacji, w której zrażona ukraińską agitacją greckokatolickich duchownych ludność z łatwością wierzyła przedstawicielom Warszawsko-Chełmskiego Konsystorza Prawosławnego i działaczom rusofilskim. Nabierając znaczenia politycznego, konflikt wyznaniowy stał się więc czynnikiem dezintegracyjnym dla jedności wyznaniowej Łemków, a zważywszy, że wyznanie było dla nich jednym z głównych wyróżników tożsamościowych - także jedności etnicznej.

\footnotetext{
${ }^{23}$ Archiwum Akt Nowych [dalej: AAN], Ministerstwo Wyznań Religijnych i Oświecenia Publicznego [dalej: MWRiOP], 1043, Pismo Starostwa jasielskiego do Urzędu Wojewódzkiego w Krakowie z dnia 24 października 1927 r., k. 50; tamże, Pismo mieszkańców wsi Bogusza i Królowa Wielka do Ministerstwa Wyznań Religijnych i Oświecenia Publicznego w Warszawie, k. 52. Por. ANK, Urząd Wojewódzki Krakowski [dalej: UW], 268, Sprawozdanie Krakowskiego Urzędu Wojewódzkiego z dnia 11 czerwca 1928 r. k. 575; tamże, UW, 596, Sprawozdanie sytuacyjne starostwa powiatowego w Grybowie z dnia 8 listopada 1928 r., k. 21.

${ }^{24}$ A. Krochmal, Stosunki między grekokatolikami i prawosławnymi na Łemkowszczyźnie w latach 1926-1939, w: Łemkowie w historii, s. 291; K. Nowakowski, Sytuacja polityczna na Łemkowszczyźnie, w: Łemkowie whistorii, s. 325.

25 AAN, MWRiOP, 1043, Pismo Ministerstwa Wyznań Religijnych i Oświecenia Publicznego do Metropolity Kościoła Prawosławnego w Polsce z dn. 25 stycznia 1928 r., k. 174.

${ }^{26}$ A. Krochmal, Stosunki, s. 289.
} 
Konwersja Łemków na prawosławie została zahamowana na początku lat trzydziestych; nie zakończyło to jednak konfliktu wyznaniowego na badanym obszarze. W dalszym ciągu najwięcej kontrowersji budziła wśród wiernych prowadzona przez greckokatolickich duchownych akcja ukrainizacyjna, do której wykorzystywane były święta kościelne i odpusty. Z inicjatywy działaczy staroruskich i we współpracy z władzami RP powołana została dla Łemkowszczyzny odrębna od diecezji greckokatolickiej w Przemyślu struktura kościelna, która miała zatrzymać ukrainizację Łemków. Administracja Apostolska Łemkowszczyzny powstała w 1934 r., obejmując m.in. dekanaty sądeckie - grybowski i muszyński; Nowy Sącz i Słotwiny stały się natomiast ekspozyturami ${ }^{27}$. Wsparcie stronnictwa staroruskiego przez władze wpisywało się w polską politykę narodowościową, której początkowym celem było powstrzymanie ukrainizacji Łemków i ich asymilacja państwowa. Warto dodać, że po 1936 r. w polityce tej nastąpiła zmiana: nowy projekt zakładał poddanie ludności łemkowskiej asymilacji narodowej.

\section{Zmiana struktury społecznej Łemków w wyniku wysiedleń do USRR i na ziemie poniemieckie}

Po zakończeniu drugiej wojny światowej na terenie powiatu nowosądeckiego żyło ok. 23 tys. Łemków ${ }^{28}$. Trudności z dokładnym oszacowaniem ich liczby wynikają z mało wiarygodnych źródeł: prowizorycznych spisów ludności przeprowadzonych w czasie migracji związanej z akcją

${ }^{27}$ M. Lewandowska, Administracja Apostolska Łemkowszczyzny, ,Płaj”, 27, 2003, s. 46. Więcej zob.: S. Stępień, Organizacja i struktura terytorialna greckokatolickiej diecezji przemyskiej w latach 1918-1939, w: Polska Ukraina. 1000 lat sąsiedztwa. Studia z dziejów greckokatolickiej diecezji przemyskiej, t. 3, red. S. Stępień, Przemyśl 1996; P. Best, Apostolska Administracja Łemkowszczyzny 1934-1944, w: Polska - Ukraina. Studia z dziejów greckokatolickiej diecezji przemyskiej, t. 4, red. S. Stępien, Przemyśl 1998; K. Nowakowski, Apostolska Administracja Łemkowszczyzny w latach 1939-1947, w: Polska - Ukraina, t. 3.

${ }^{28}$ Protokót końcowy przesiedlenia Ukraińców z powiatu nowosądeckiego do USSR, w: Repatriacja czy deportacja. Przesiedlenie Ukraińców z Polski do USRR. Dokumenty, t. 2, red. E. Misito, Warszawa 1999, dok. 74, s. 152. przesiedleńczą do USRR w latach 1945 1946, rozbieżnych spisów wysiedleńczych, a także prób ukrycia tożsamości podejmowanych przez osoby chcące uniknąć wysiedlenia $^{29}$. Widoczny spadek liczby ludności w stosunku do roku 1939 był wynikiem drugiej wojny światowej i akcji przesiedleńczej z 1940 r., przeprowadzonej zgodnie z porozumieniem o wymianie ludności zawartym 16 listopada 1939 r. pomiędzy rządami III Rzeszy i ZSRR. Prawem do wyjazdu objęci zostali wówczas Ukraińcy, do których zaliczono również Łemków ${ }^{30}$. W rozpoczętych 1 marca 1940 r. przesiedleniach ludność łemkowska kierowana była do obwodu tarnopolskiego ${ }^{31}$. Do USRR wyjechało wówczas 11 tys. osób, w tym ok. 5 tys. Łemków ${ }^{32}$. Z niekompletnej dokumentacji niemieckiego okupanta wynika, że z Sądecczyzny przesiedlono przynajmniej 239 osób, w tym 54 z gminy Łabowa ${ }^{33}, 21$ z gminy Tylicz ${ }^{34}, 14$ z miejscowości Krynica-Wieś35, a z samej Królowej Ruskiej - $150^{36}$. Łącznie zachodnią Łemkowszczyznę (powiaty: nowotarski, nowosądecki i gorlicki) opuściło w tym czasie 3530 osób $^{37}$. Pierwsze powroty nastąpiły w $1941 \mathrm{r}^{38} \mathrm{Z}$ niepełnego materiału

\footnotetext{
${ }_{29}$ J. Pisuliński, Polityka władz wobec społeczności ukraińskiej w latach 1944-1956, „Pamięć i Sprawiedliwość”, 3/2 (6), 2004, s. 162.

${ }^{30}$ R. Torzecki, Kwestia ukraińska w polityce III Rzeszy (1933-1945), Warszawa 1972, s. 194; В. Кубійович, Українці в Генеральній Губернії 1939-1941 - Історія Українського Центрального Комітету, Чікаго 1975, s. 182; A. Kwilecki, Łemkowie. Zagadnienie migracji i asymilacii, Warszawa 1974, s. 80.

${ }^{31}$ В. Кубійович, Українці , s. 180, 182.

${ }_{32}$ R. Torzecki, Kwestia, s. 194; В. Кубійович, Українці, s. 182.

${ }_{33}$ Archiwum Narodowe w Krakowie Oddział w Nowym Sączu [dalej: ANNS], Powiatowy Urząd Repatriacyjny [dalej: PUR], 23, Wykaz majątków poukraińskich, których właściciele wyjechali w r. 1940 do Rosji Sowieckiej z gminy Łabowa, k. 51 .

${ }^{34}$ Tamże, Wykaz majątków poukraińskich, których właściciele wyemigrowali w r. 1940 do Rosji Sowieckiej z gminy Tylicz, k. 53.

${ }^{35}$ Tamże, Spis majątków poukraińskich tych właścicieli, którzy wyemigrowali w r. 1940 do Rosji Sowieckiej z Krynicy Wsi, k. 47.

36 Tamże, Wykaz osób, które wyjechały do Rosji Sowieckiej z Królowej Ruskiej w 1940 r., z dn. 19 || 1943, k. 1; tamże, Ausweis der Landwirte, die im Jahre 1940 aus Królowa Ruska nach Sowjetunion übersiedelt sind, k. 41; tamże, Zusammenstellung der eingesogenen Klein-Betriebe in der Ortschaft Królowa Ruska, Kreis Neu Sandez, k. 45.

${ }^{37}$ J. Pisuliński, Przesiedlenie ludności ukraińskiej z Polski do USRR w latach 1944-1947, Rzeszów 2009, s. 44.

${ }^{38}$ В. Кубійович, Українці, s. 181.
} 
źródłowego wynika, że na Sądecczyznę wróciły minimum 43 osoby - 12 do gminy Tylicz i 31 do gminy Łabowa ${ }^{39}$.

Znaczącej zmiany w strukturze ludności łemkowskiej dokonało objęcie jej akcją przesiedleńczą w myśl porozumienia zawartego 9 września 1944 r. pomiędzy Polskim Komitetem Wyzwolenia Narodowego a rządem USRR. Związana z ustaleniem wschodniej granicy Polski umowa o wymianie ludności obejmowała Ukraińców z Polski i Polaków z ZSRR, ale także rusińskie grupy etniczne, a co za tym idzie społeczność łemkowską, która liczyła wówczas ok. 100 tys. osób ${ }^{40}$. Akcja przesiedleńcza odpowiadała polityce narodowościowej polskich władz. Po ukształtowaniu się granic państwa jednym z priorytetów stało się dla nich rozwiązanie problemu dużych skupisk osób narodowości ukraińskiej w południowo-wschodniej części kraju, postrzeganych jako zaplecze dla ukraińskiego podziemia ${ }^{41}$. „Chociaż więc przesiedlenie miało mieć charakter dobrowolny, od momentu podpisania umowy prawo do samostanowienia coraz bardziej było utożsamiane wyłącznie z prawem do przesiedlenia się na Ukrainę radziecką" ${ }^{2}$.

Wysiedlenia z powiatu nowosądeckiego rozpoczęły się 19 kwietnia 1945 r. $^{43}$ Początkowo, za sprawą sowieckiej propagandy, Łemkowie zgłaszali chęć wyjazdu

\footnotetext{
${ }^{39}$ ANNS, PUR, 23, Wykaz majątków poukraińskich, których właściciele wyemigrowali w r. 1940 względnie później do Rosji Sowieckiej, Tylicz, k. 53; tamże, Wykaz majątków poukraińskich, których właściciele wyjechali w r. 1940 do Rosji Sowieckiej, gmina Łabowa, k. 51.

40 J. Pisuliński, Przesiedlenie, s. 85; J. Kwiek, Żydzi, Łemkowie, Stowacy w województwie krakowskim w latach 1945-1949/50, Kraków 2002, s. 194; K. Pudło, Dzieje Łemków po drugiej wojnie światowej, w: Łemkowie whistorii, cz. 1, s. 355; R. Drozd, Powojenne wysiedlenia Łemków polskich w latach 1944-1950, w: Łemkowie, Bojkowie, Rusini - historia, wspótczesność, kultura materialna i duchowa, [t. 1], red. S. Dudra, Zielona Góra 2007, s. 131. Por. J. Kwiek, Przesiedlenie ludności temkowskiej z województwa krakowskiego na Ukraine (1945-1946), ,Studia Historyczne”, 2, 1998.

${ }^{41}$ Protokót końcowy, s. 152.

${ }^{42}$ Cyt. za: J. Pisuliński, Polityka, s. 166.

${ }^{43}$ W porozumieniu nie wspomniano o województwie krakowskim, ponieważ trwały tam jeszcze wówczas walki wyzwoleńcze z niemieckim okupantem. Repatriacja czy deportacja. Przesiedlenie Ukraińców z Polski do USRR. Dokumenty, t. 1, red. E. Misito, Warszawa 1996, dok. 8, s. 30. Obszar ten objęto wysiedleniami w wyniku podpisanego 3 marca 1945 r. protokołu dodatkowego do ww. umowy. Oficjalnie województwo krakowskie zostało objęte przesiedleniami 25 marca 1945 r. J. Pisuliński, Przesiedlenie, s. 141.
}

do USRR, ale pod wpływem informacji o panujących tam warunkach wycofali złożone wcześniej deklaracje ${ }^{44}$. W obliczu coraz większych trudności z przeprowadzeniem akcji przesiedleńczej władze powiatowe odstępowały od zasady dobrowolności. Z drugiej strony wśród Łemków coraz częstsze były próby uniknięcia wyjazdu: 1200 osób zadeklarowało narodowość polską $^{45}$, a przynajmniej $800 \mathrm{z}$ nich zmieniło wyznanie z greckokatolickiego na rzymskokatolickie ${ }^{46}$. Zahamowanie przesiedleń spowodowało, że władze zadecydowały o przeprowadzeniu akcji przy pomocy wojska ${ }^{47}$. Nie uwzględniając wewnętrznego zróżnicowania tożsamościowego ludności łemkowskiej, przypisano jej całościowo narodowość ukraińską.

Między kwietniem 1945 a czerwcem 1946 r. z powiatu nowosądeckiego wysiedlono łącznie 17666 osób (77 proc.) (tab. 1$)^{48}$. Szacunki liczby mieszkańców, którzy pozostali na tym terenie, wahają się w dokumentacji archiwalnej od 5193 do 8433. Starosta nowosądecki w piśmie do Wydziału Społeczno-Politycznego Urzędu Wojewódzkiego w Krakowie na temat stanu liczebnego mniejszości narodowych informował o 5618 Łemkach i 2825 Ukraińcach (przeważnie Łemkach o ukraińskiej tożsamości narodowej ${ }^{49}$. Według sprawozdań władz lokalnych liczba osób niewysiedlonych wynosiła: w mieście Krynica - 51, w gminie Krynica-Wieś - 151,

44 Tamże.

45 Protokót końcowy, s. 151.

${ }^{46}$ ANNS, Starostwo Powiatowe w Nowym Sączu [dalej: StPNS], 92, Wypis familijny parafii rzymskokatolickiej, Urząd Parafialny w Nowym Sączu 4 października 1945 r., k. 19; tamże, Pismo starosty nowosądeckiego do greckokatolickiego urzędu parafialnego w Rzeszowie, 16 stycznia $1946 \mathrm{r}$., k. 87; ANNS, StPNS, 98, Pismo sottysa Królowej Ruskiej do Starostwa Powiatowego w Nowym Sączu, 9 lutego 1946 r., k. 229; tamże, 92, Pismo 0 zmianę wyznania z Wierchomli Wielkiej, październik 1945 r., k. 57.

47 ANNS, Powiatowa Rada Narodowa, 5, Posiedzenie Powiatowej Rady Narodowej odbyte w dniu 20 listopada 1945 r. w sali wydziału powiatowego w Nowym Sączu, k. 78.

48 Protokół końcowy, s. 152.

${ }^{49}$ ANNS, StPNS, 99, Pismo starosty powiatowego nowosądeckiego Józefa Łabuza do Urzędu Wojewódzkiego Wydziału Społeczno-Politycznego w Krakowie dotyczące stanu liczebnego mniejszości narodowych, 9 listopada 1946 r., k. 239. 
Tabela 1. Ludność temkowska wysiedlona z powiatu nowosądeckiego w latach 1945-1946 (wg gmin)

\begin{tabular}{|l|c|c|c|c|}
\hline \multirow{2}{*}{\multicolumn{1}{c|}{ Gmina }} & \multicolumn{2}{c|}{$\begin{array}{c}\text { Zakwalifikowano } \\
\text { do przesiedlenia }\end{array}$} & \multicolumn{2}{c|}{$\begin{array}{c}\text { Wysiedlono } \\
\text { od IV 1945 } \\
\text { do VI 1946 r. }\end{array}$} \\
\cline { 2 - 5 } & rodzin & osób & rodzin & osób \\
\hline Nowy Sącz & 48 & 252 & 42 & 152 \\
\hline Krynica & 156 & 658 & 147 & 598 \\
\hline Krynica-Wieś & 542 & 2127 & 488 & 1980 \\
\hline Labowa & 664 & 3252 & 604 & 2884 \\
\hline Muszyna & 1146 & 5292 & 1053 & 4849 \\
\hline Nawojowa & 171 & 1100 & 170 & 932 \\
\hline Tylicz & 868 & 5464 & 672 & 3098 \\
\hline Grybów & 342 & 2818 & 292 & 1399 \\
\hline Piwniczna & 413 & 1896 & 385 & 1774 \\
\hline Razem & 4350 & 22859 & 3853 & 17666 \\
\hline
\end{tabular}

Źródło: Protokót końcowy przesiedlenia Ukraińców z powiatu nowosądeckiego do USSR, w: Repatriacja czy deportacja, s. 152

w gminie Łabowa - 1502, w gminie $\mathrm{Mu}-$ szyna - 2494, w gminie Nawojowa - 126, w mieście Nowy Sącz - 39, w gminie Tylicz $-2320^{50}$. Akcja przebiegała w trzech falach: do połowy lipca 1945 r. przesiedlono 13100 osób, od połowy lipca do grudnia - 4412, a w 1946 - łącznie 228, $\mathrm{w}$ tym $60 \mathrm{z}$ pomoca wojska $\mathrm{w}$ ostatnim etapie wywózek. Największą intensywność wyjazdów odnotowujemy od kwietnia do połowy lipca 1945 r., kiedy jeszcze ludność łemkowska miała do nich pozytywny stosunek $^{51}$. Załamanie nastąpiło na przełomie lipca i sierpnia 1945 r., do czego przyczyniły się m.in. stopniowe powroty przesiedlonych osób oraz zdemobilizowanych żołnierzy Armii Czerwonej, którzy informowali o fatalnych warunkach

\footnotetext{
${ }^{50}$ Tamże, Pismo burmistrza Krynicy do Starostwa Powiatowego w Nowym Sączu dotyczące stanu liczebnego mniejszości narodowych, 14 października 1946 r., k. 251.

${ }^{51} 0$ początkowym nastawieniu temków do wysiedlenia zob. m.in.: A. Kwilecki, Fragmenty najnowszej historii Łemków ze szczególnym uwzględnieniem Łemków Sądeckich, Warszawa 1970, s. 275; J. Pisuliński, Przesiedlenie, s. 293.
}

panujących w USRR ${ }^{52}$. Zjawisko powrotów przesiedlanej ludności nie pozostaje bez wpływu na problem oszacowania dokładnej liczby wysiedlonych i pozostałych na terenie powiatu Łemków.

Przesiedlenia do USRR nie przyniosły wyników satysfakcjonujących władze Polski, gdyż według szacunków w południowo-wschodniej części kraju miało pozostać ok. 100-110 tys. osób pochodzenia ukraińskiego. W opinii rządu ludność ta miała stanowić zaplecze dla oddziałów Ukraińskiej Powstańczej Armii, w związku z czym od stycznia 1947 r. prowadzono wstępne przygotowania do częściowego przesiedlenia jej na ziemie zachodnie i północne ${ }^{53}$. O likwidacji UPA i przesiedleniu pozostałej w kraju ludności ukraińskiej w celu jej rozproszenia i asymilacji zadecydowano 17 kwietnia 1947 r. na posiedzeniu Państwowego Komitetu Bezpieczeństwa, a następnie zatwierdzono to uchwałą Prezydium Rady Ministrów z 24 kwietnia 1947 r. ${ }^{54}$ Wpływ na represyjny charakter akcji miała śmierć wiceministra obrony narodowej gen. Karola Świerczewskiego, zabitego 28 marca 1947 r. w zasadzce oddziału UPA pod Jabłonkami w Bieszczadach ${ }^{55}$.

\footnotetext{
52 Sprawozdanie końcowe Wydziału Operacyjnego Dowództwa Okręgu Wojskowego nr V (Krakowskiego) dla Sztabu Generalnego WP z przesiedlenia Ukraińców z województwa krakowskiego do USRR, w: Repatriacja czy deportacja, t. 1, dok. 139, s. 269.

53 R. Drozd, Ukraińcy w Polsce 1944-1947-losy, postawy, nastroje, w: Akcja „Wista”, red. J. Pisuliński, Warszawa 2003, s. 79; E. Mironowicz, Polityka władz Polski Ludowej wobec Ukraińców w latach 1944-1947, w: Akcja „Wista”, red. J. Pisuliński, s. 61; J. Pisuliński, Akcja Specjalna "Wista”, Rzeszów 2017, s. 33; S. Dudra, temkowie. Deportacje i osadnictwo ludności temkowskiej na środkowym Nadodrzu w latach 1947-1960, Głogów 1998, s. 22. Por.: tenże, Akcja „Wista” na Łemkowszczyźnie, „Rocznik Sądecki”, 26, 1998; L. Olejnik, Problem ukraiński w polityce narodowościowej państwa polskiego w latach 1944-1957, w: Polska i Ukraina po Il wojnie światowej, red. W. Bonusiak, Rzeszów 1998.

54 S. Dudra, Łemkowie. Deportacje, s. 23; J. Kwiek, Żydzi, s. 230; J. Pisuliński, Akcja; Zarządzenie Państwowej Komisji Bezpieczeństwa dla Grupy Operacyjnej Wista, w: Akcja „Wista”. Dokumenty i materiały, oprac. E. Misito, Warszawa 2013, dok. 44, s. 98; Uchwała Prezydium Rady Ministrów w sprawie przeprowadzenia deportacji Ukraińców w ramach akcji Wista, w: Ukraińcy w Polsce 1944-1989. Walka o tożsamość (dokumenty i materiaty), oprac. R. Drozd, I. Hałagida, Warszawa 1999, dok. 10, s. 48.

55 S. Dudra, Łemkowie. Deportacje, s. 22; Telefonogram Dowództwa Okręgu Krakowskiego do szefa Sztabu Generalnego WP gen. broni Wt. Korczyca, informujący o śmierci wiceministra obrony narodowejgen. broni K. Świerczewskiego, w: Akcja „Wista”. Dokumenty, dok. 17, s. 63; Raport szefa
} 


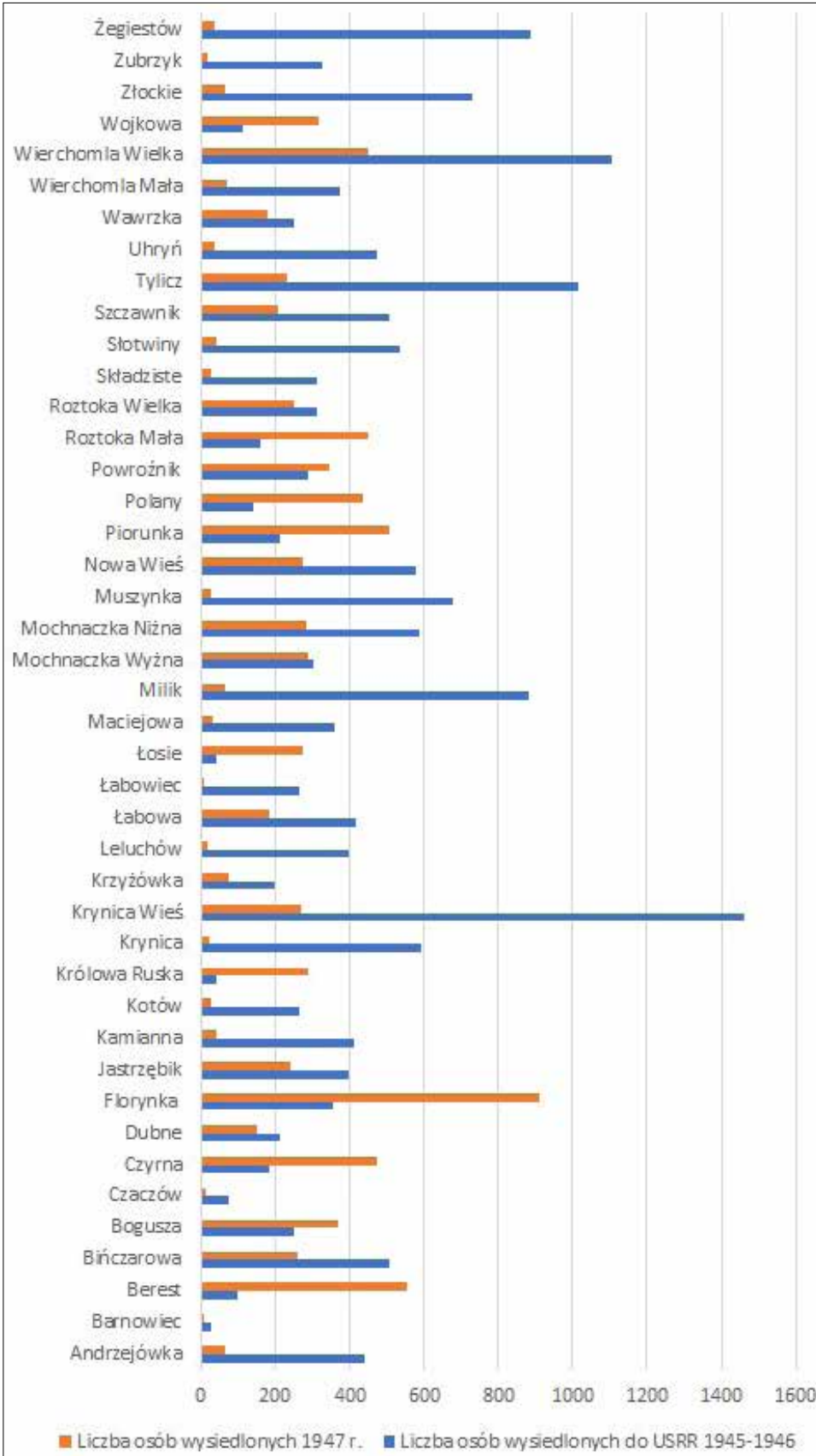

Ryc. 5. Liczba ludności temkowskiej wysiedlonej w latach 1945-1946 i 1947 z poszczególnych miejscowości powiatu nowosadeckiego.

Źródto: oprac. własne na podstawie: „Protokót końcowy”, s. 152; AAN, 527, Rejonowy Przedstawiciel RP do Spraw Ewakuacji w Nowym Sączu 1191/5, Sprawozdania z przebiegu ewakuacji Iudności ukraińskiej i innej do USRR, stan na dzień 31 grudnia 1945 r., k. 13; tamże, Sprawozdanie z przebiegu ewakuacji ludności ukraińskiej i innej do USRR, stan na dzień 31 maja 1946 r., k. 16; ANNS, PUR, 113/31/47, Imienny wykaz przesiedlonej ludności temkowskiej z powiatu Nowy Sącz; AIPN, MSW, 00231/92, t. 81, Wykaz ilościowy ludności wysiedlonej i pozostawionej na miejscu w pow. Nowy Sącz w okresie od 30 czerwca - 4 lipca 1947 r., k. 197-210; tamże, Zestawienie ludności i sprzętu z powiatu Nowy Sącz w okresie od 5 do 9 lipca 1947 r., k. 196

Wydarzenie to zostało wykorzystane w propagandzie nawołującej do wysiedlenia

Wydziału Operacyinego Oddziału III Sztabu Generalnego WP pptk. Kossowskiego dla szefa Sztabu Generalnego WP Wt. Korczyca w sprawie okoliczności śmierci gen. broni K. Świerczewskiego, w: Akcja "Wista”. Dokumenty, dok. 33, s. 82. ludności pomówionej o współpracę z ukraińskim podziemiem.

Akcja „Wisła” trwała na Łemkowszczyźnie od 28 kwietnia do 15 lipca 1947 r. Wysiedlenia z powiatu nowosądeckiego rozpoczęły się 27 czerwca, obejmując 
44 miejscowości ${ }^{56}$. Łącznie odesłano stąd 33 transporty, przesiedlając przymusowo ok. 8867 osób (1779 rodzin) (tab. 2). Liczbę tę potwierdzają imienne spisy wysiedleńcze $^{57}$, co prowadzi do wniosku, że statystyki podawane m.in. przez Eugeniusza Misiłę są zawyżone ${ }^{58}$. W czerwcu na stacjach załadowczych w powiecie nowosądeckim sformowano 6 transportów liczących łącznie 180 wagonów ${ }^{59}$. Na stacji etapowej w Oświęcimiu następowało rozdzielanie mieszkańców poszczególnych wsi i kierowanie ich do różnych zakątków Polski. Ludność łemkowska z powiatu nowosądeckiego rozlokowana została na ziemiach poniemieckich, w znacznej mierze na obszarze województw wrocławskiego i poznańskiego, zwłaszcza w Ziemi Lubuskiej $^{60}$. Plany osadnicze zakładały lokowanie w danej miejscowości jednej rodziny z konkretnego transportu i niedopuszczenie, by przesiedleńcy stanowili więcej niż 10 proc. ogółu mieszkańców ${ }^{61}$. Największa intensyfikacja akcji przypadła na okres od 30 czerwca do 4 lipca 1947 r., kiedy z powiatu nowosądeckiego wysiedlono ok. 1042 łemkowskich rodzin, tj. 5356 osób, co stanowi 60 proc. ludności zakwalifikowanej do przymusowej deportacji ${ }^{62}$;

\footnotetext{
${ }^{56}$ Archiwum Instytutu Pamięci Narodowej w Warszawie [dalej: AIPN], MSW, 00231/92, t. 81, Wykaz ilościowy ludności wysiedlonej i pozostawionej na miejscu w pow. Nowy Sącz w okresie od 30 czerwca - 4 lipca 1947 r., k. 210; ANNS, PUR, 31/113/51, Wykaz wysiedlonych z powiatu nowosądeckiego; AIPN, MSW, 00231/92, t. 81, Wykaz ludności wysiedlonej i pozostawionej na miejscu w okresie od 10 do 14 lipca 1947 r., k. 210.

${ }^{57}$ ANNS, PUR, 31/113/47, Imienny wykaz przesiedlonej ludności łemkowskiej z powiatu Nowy Sącz.

${ }^{58}$ Akcja „Wista”. Dokumenty, s. 1013-1014.

${ }^{59}$ AIPN, MSW, 00231/92, t. 77, Sprawozdanie z wykonanych czynności wydziału komunikacji GO Wisła za miesiąc czerwiec 1947 r., k. 13; ANK, UW, II, 1081, Pismo starosty powiatowego nowotarskiego do Urzędu Wojewódzkiego w Krakowie z dn. 22 sierpnia 1947 r., k. 175.

${ }^{60}$ Archiwum Państwowe w Zielonej Górze, Urząd Wojewódzki Poznański, 1311, Sprawozdanie z otrzymanych transportów w ramach akcji "W" na terenie powiatu Strzelce Krajeńskie, k. 189.

${ }^{61}$ Instrukcja MZO dotycząca zasad osiedlania rodzin ukraińskich, w: Ukraińcy w Polsce, dok. 13, s. 53

${ }^{62}$ AIPN, MSW, 00231/92, t. 81, Wykaz ilościowy ludności wysiedlonej i pozostawionej na miejscu w pow. Nowy Sącz w okresie od 30 czerwca - 4 lipca 1947 r., k. 210; tamże, Zestawienie ludności i sprzętu z powiatu Nowy Sącz w okresie od 5 do 9 lipca 1947 r., k. 196; tamże, Zestawienie przesiedlonej ludności i sprzętu w okresie od 10 do 14 lipca 1947 r., k. 209; tamże, Wykaz ludności wysiedlonej i pozostawionej na miejscu w okresie od
}

pozostało tam natomiast przynajmniej 529 osób $^{63} \cdot 10$ zwolniono z obowiązku wyjazdu ze względu na specjalne zasługi, a poza tym wyrażano zgodę na pozostawianie osób potrzebnych do utrzymywania sprawnej działalności gospodarczej terenu. Większość ludności nieobjętej wywózką zajmowała się rolnictwem, a w 99 proc. należała do Kościoła greckokatolickiego. Osoby te pochodziły najprawdopodobniej z rodzin polsko-łemkowskich ${ }^{64}$. Warto podkreślić, że przyczyną przesiedlenia Łemków z powiatu nowosądeckiego nie mogła być działalność oddziałów UPA, ponieważ na całej Sądecczyźnie była ona nieznaczna ${ }^{65}$.

W wyniku wysiedlenia w latach $1945-$ 1947 ok. 25,5 tys. osób (ryc. 5) struktura narodowo-etniczna łemkowskich wiosek w powiecie nowosądeckim uległa gwałtownej zmianie, zwłaszcza w obliczu przekazania majątków ludności polskiej (miejscowej, która utraciła dobytek m.in. $\mathrm{w}$ wyniku wojny, oraz napływowej z innych powiatów i 66 przesiedleńcom ze Wschodu ${ }^{66}$. Zniszczeniu uległa nie tylko społeczna, ale także wyznaniowa struktura

10 do 14 lipca 1947 r., k. 210; tamże, t. 77, Sprawozdanie z przebiegu akcj przesiedlenia ludności ukraińskiej na terenie działania Grupy Operacyjnej „Wisła" na czas od 6 do 15 lipca 1947 r., k. 10.

63 Według imiennych spisów sporządzonych przez Urząd Bezpieczeństwa na terenie powiatu nowosądeckiego pozostało 529 Łemków, w tym: 11 osób w Muszynie, 7 w Andrzejówce, 4 w Baranowcu, 2 w Binczarowej, 3 w Czaczowie, 5 w Dubnem, 9 we Florynce, 4 w Grybowie, 4 w Jastrzębiku, 3 w Królowej Ruskiej, 38 w Krynicy-Wsi, 103 w Krynicy-Zdroju, 6 w Leluchowie, 29 w Łabowej, 3 w Maciejowej, 8 w Miliku, 4 w Nawojowej, 19 w Nowej Wsi, 93 w Nowym Sączu, 2 w Piwnicznej, 13 w Powroźniku, 3 w Szczawniku, 130 w Tyliczu, 1 w Wawrzce, 1 w Wierchomli Małej, 13 w Wierchomli Wielkiej, 1 w Wojkowej, 2 w Ztockiem, 2 w Zubrzyku i 6 w Żegiestowie. Archiwum Instytutu Pamięci Narodowej w Krakowie [dalej: AIPN Kr], Wojewódzki Urząd Spraw Wewnętrznych w Krakowie [dalej: WUSWK], 075/8, t. 4, Wykaz pozostałych Łemków/Ukraińców na terenie powiatu nowosądeckiego, k. 11-25.

64 Tamże.

${ }^{65}$ G. Motyka, Ukraińska Powstańcza Armia a akcja „Wista”, w: Akcja „Wista”, red. J. Pisuliński, s. 112; AIPN Kr, WUSWK, 075/8, t. 7, Raport z przebiegu likwidacji bandy UPA za okres 3 kwietnia - 10 kwietnia 1947 r., k. 134.

${ }^{66}$ Po wysiedlonej ludności temkowskiej na terenie powiatu pozostało 14 tys. ha gruntów oraz 1,7 tys. domostw, z czego utworzono 960 gospodarstw obejmujących po ok. 10 ha gruntów. AIPN, MSW, 00231/92, t. 77, Wykaz mienia pozostałego po wysiedlonych Ukraińcach w pow. Nowy Sącz, k. 189; ANNS, PUR, 31/113/24, Pismo starosty powiatowego nowosądeckiego Wacława Wojtuszaka do wójta gminy w sprawie zabezpieczenia mienia połemkowskiego z 16 czerwca 1947 r., k. 46. 
Tabela 2. Wykaz osób przesiedlonych z powiatu nowosądeckiego w ramach akcji "Wista” od 30 czerwca do 15 lipca 1947 r.

\begin{tabular}{|c|c|c|c|}
\hline \multirow{2}{*}{$\begin{array}{c}\text { Nazwa } \\
\text { miejscowości }\end{array}$} & \multirow{2}{*}{$\begin{array}{c}\text { Data } \\
\text { wysiedlenia }\end{array}$} & \multicolumn{2}{|c|}{ Liczba wysiedlonych } \\
\hline & & rodzin & osób \\
\hline Andrzejówka & $6-15$ VII & 20 & 63 \\
\hline Baranowiec & $6-15$ VII & 1 & 7 \\
\hline Berest & $1-5 \mathrm{VII}$ & 99 & 554 \\
\hline Binczarowa & $1-5 \mathrm{VII}$ & 53 & 261 \\
\hline Bogusza & $1 \mathrm{VII}$ & 73 & 368 \\
\hline Czaczów & $6-15 \mathrm{VII}$ & 2 & 12 \\
\hline Czyrna & $6-15 \mathrm{VII}$ & 88 & 473 \\
\hline Dubne & $6-15 \mathrm{VII}$ & 26 & 148 \\
\hline Florynka & $1-15 \mathrm{VII}$ & 177 & 909 \\
\hline Frycowa & $6-15 \mathrm{VII}$ & 3 & 12 \\
\hline Jastrzębik & $6-15$ VII & 51 & 241 \\
\hline Kamianna & $1-5 \mathrm{VII}$ & 7 & 40 \\
\hline Kotów & $1-5 \mathrm{VII}$ & 5 & 28 \\
\hline Królowa Ruska & $1-5 \mathrm{VII}$ & 51 & 290 \\
\hline Krynica & $1-5 \mathrm{VII}$ & 7 & 22 \\
\hline Krynica-Wieś & $1-5 \mathrm{VII}$ & 54 & 270 \\
\hline Krzyżówka & $1-5 \mathrm{VII}$ & 14 & 72 \\
\hline Leluchów & $6-15 \mathrm{VII}$ & 3 & 17 \\
\hline Łabowa & $6-15$ VII & 34 & 181 \\
\hline Łabowiec & $\cdot$ & · & 9 \\
\hline Łosie & $1-5 \mathrm{VII}$ & 45 & 273 \\
\hline Maciejowa & $6-15 \mathrm{VII}$ & 8 & 33 \\
\hline Milik & $6-15$ VII & 18 & 63 \\
\hline Mochnaczka Wyżna & $1-5 \mathrm{VII}$ & 62 & 290 \\
\hline Mochnaczka Niżna & $1-5 \mathrm{VII}$ & 54 & 284 \\
\hline Muszyna & $6-15$ VII & 4 & 26 \\
\hline Muszynka & $1-5 \mathrm{VII}$ & 50 & 274 \\
\hline Nowa-Wieś & 6-15 VII & 105 & 505 \\
\hline Piorunka & $1-5 \mathrm{VII}$ & 79 & 434 \\
\hline Polany & $1-5 \mathrm{VII}$ & 62 & 343 \\
\hline Powroźnik & $6-15$ VII & 104 & 451 \\
\hline
\end{tabular}

\begin{tabular}{|l|c|c|c|}
\hline Roztoka Wielka & $6-15 \mathrm{VII}$ & 32 & 252 \\
\hline Składziste & $6-15 \mathrm{VII}$ & 6 & 28 \\
\hline Słotwiny & $6-15 \mathrm{VII}$ & 14 & 39 \\
\hline Szczawnik & $6-15 \mathrm{VII}$ & 46 & 207 \\
\hline Tylicz & $1-5 \mathrm{VII}$ & 44 & 231 \\
\hline Uhryń & $1-5 \mathrm{VII}$ & 10 & 35 \\
\hline Wawrzka & $1-5 \mathrm{VII}$ & 32 & 179 \\
\hline Wierchomla Mała & $6-15 \mathrm{VII}$ & $?$ & 67 \\
\hline Wierchomla Wielka & $6-15 \mathrm{VII}$ & $?$ & 448 \\
\hline Wojkowa & $6-15 \mathrm{VII}$ & 60 & 315 \\
\hline Złockie & $6-15 \mathrm{VII}$ & 16 & 66 \\
\hline Zubrzyk & $14 \mathrm{VII}$ & $?$ & 17 \\
\hline Żegiestów & $6-15 \mathrm{VII}$ & 19 & 37 \\
\hline
\end{tabular}

Źródło: oprac. własne na podstawie: ANNS, PUR, 113/31/47, Imienny wykaz przesiedlonej ludności temkowskiej z powiatu Nowy Sącz; AIPN, MSW, 00231/92, t. 81, Wykaz ilościowy ludności wysiedlonej i pozostawionej na miejscu w pow. Nowy Sącz w okresie od 30 czerwca - 4 lipca 1947 r., k. 197-210; tamże, Zestawienie ludności i sprzętu z powiatu Nowy Sącz w okresie od 5 do 9 lipca 1947 r., k. 196; tamże, Zestawienie przesiedlonej ludności i sprzętu w okresie od 10 do 14 lipca 1947 r., k. 209; tamże, Wykaz ludności wysiedlonej i pozostawionej na miejscu w okresie od 10 do 14 lipca 1947 r., k. 210; AIPN, MSW, 00231/92 t. 77, Sprawozdanie z przebiegu akcji przesiedlenia ludności ukraińskiej na terenie działania Grupy Operacyjnej „Wista” na czas od 6 do 15 lipca 1947 r., k. 10; Akcja „Wista”. Dokumenty, s. 1013-1014

Łemkowszczyzny. Wraz z wiernymi wyjechali greckokatoliccy i prawosławni duchowni, więc zdezorganizowana została struktura administracyjna obu Kościołów ${ }^{67}$. Ludność łemkowska, zamieszkująca dotąd zwarte terytorium etniczne, została całkowicie rozproszona, w wyniku czego uległa pełnej dezintegracji i asymilacji w nowym miejscu zamieszkania ${ }^{68}$. Roz-

${ }^{67}$ S. Dudra, Poza małą ojczyzną. Łemkowie na Ziemi Lubuskiej, Wrocław 2008, s. 155

68 Tamże; S. Dudra, Łemkowie. Deportacie; tenże, Integracyina i kulturotwórcza rola Cerkwi wżyciu prawostawnych Łemków, w: Łemkowie, red. B. Machul-Telus; tenże, Łemkowie na środkowym Nadodrzu (1947-1956), ,Studia Zachodnie", 4, 1999; tenże, Łemkowie wobec przemian politycznych 1956 roku w Polsce, w: Łemkowie, Bojkowie, [t. 1]; tenże, Życie religjine Łemków wyznania prawosławnego na ziemiach zachodniej Polski po akcji "Wista", „Płaj”, 28, 2004; K. Pudło, Dzieje; tenże, Łemkowie na Dolnym Śląsku (1947-1982), „Rocznik Dolnośląski”, 9, 1985; tenże, temkowie. Proces wrastania w środowisko Dolnego Śląska 1947-1985, „Prace i Materiały Etnograficzne”, 28, 1987; A. Kwilecki, Liczebność i rozmieszczenie grup mniejszości narodowych na Ziemiach Zachodnich, „Przegląd Zachodni”, 4 1964; tenże, Łemkowie na Ziemi Lubuskiej, „Nadodrze”, 5, 1966; tenże, 
proszenie doprowadziło do ostatecznego zakończenia procesu podziału tej grupy etnicznej na środowiska łemkowskie (odwołujące się do korzeni staroruskich) oraz proukraińskie (utożsamiające się $\mathrm{z}$ narodowością ukraińską z odwołaniem do regionalnej kultury łemkowskiej). Znaczna część Łemków, zwłaszcza z młodego pokolenia, uległa polonizacji ${ }^{69}$. $\mathrm{Na}$ teren powiatu nowosądeckiego powróciło niewiele osób: w 1977 r. mieszkało w nim ok. 700 Łemków $^{70}$, a w 2002 - 162 Łemków i 45 Ukraińców (prawdopodobnie Łemków o ukraińskiej tożsamości narodowej) $)^{71}$.

\section{Zakończenie}

Na ukształtowanie społeczności łemkowskiej wpływały czynniki polityczne i geograficzne: górski charakter zamieszkiwanego terytorium, odizolowanie od ukraińskich miast, sąsiedztwo z ludnością polską i słowacka, a także polityka narodowościowa państw ościennych. Większość łemkowskich miejscowości charakteryzowała się jednolitą strukturą etniczną i wyznaniową. W 70 proc. sądeckich wsi zamieszkanych

Fragmenty najnowszej historii Łemków, „Rocznik Sądecki”, 8, 1967; tenże, Łemkowie. Zagadnienie; tenże, Problemy socjologiczne Łemków na Ziemiach Zachodnich. Uwagi teoretyczne i terminologiczne, „Kultura i Społeczeństwo”, 3, 1966; tenże, Zagadnienia stabilizacji Łemków na Ziemiach Zachodnich, ,Przegląd Zachodni”, 6, 1966; tenże, Aktualne zagadnienia etniczne temków w Polsce, „Etnografia Polska”, 12, 1968; tenże, Zzagadnień historycznych ietnicznych dawnej Łemkowszczyzny, ,Lud”, 53, 1969; tenże, Wspótżycie z ludnością polską i przemiany kulturalne w grupie Łemków, „Etnografia Polska”, 14, 1970; tenże, Fragmenty najnowszej historii Łemków ze szczególnym uwzględnieniem Łemków Sądeckich.

${ }^{69}$ Według spisu powszechnego z 2002 r. Polskę zamieszkiwało 5,9 tys. Łemków. Wyniki Narodowego Spisu Powszechnego Ludności i Mieszkań 2002 (https://stat.gov.pl/cps/rde/xbcr/gus/raport z wynikow nsp ludnosci___mieszkan_2002.pdf, dostęp: 18 września 2020). Dane na temat liczby i rozmieszczenia ludności łemkowskiej w 2002 r. opracował Marek Barwiński: M. Barwiński, Rozmieszczenie i liczebność Łemków w Polsce na podstawie wyników spisu powszechnego z 2002 roku - uwarunkowania i kontrowersje, w: temkowie, Bojkowie, Rusini - historia, wspótczesność, kultura materialna i duchowa, t. 2, red. S. Dudra, Zielona Góra 2009.

${ }^{70}$ ANNS, Wydział Spraw Wewnętrznych UW w Nowym Sączu, 31/308/701, Wykaz jednostek, w których występują mniejszości narodowe, z dn. 31 grudnia 1977 r., k. 3.

71 Wyniki Narodowego Spisu Powszechnego Ludności i Mieszkań 2002 w zakresie deklarowanej narodowości oraz języka używanego w domu, „Gtówny Urząd Statystyczny" (https://stat.gov.pl/spisy-powszechne/ narodowe-spisy-powszechne/narodowy-spis-powszechny-2002/wyniki-narodowego-spisu-powszechnego-2002-narodowosci-oraz-jezyka/, dostęp: 18 września 2020). przez Łemków stanowili oni zdecydowaną większość (95-100 proc.). Na zmiany w liczebności tej grupy wpłynęły obie wojny światowe, emigracja zarobkowa w pierwszych latach drugiej dekady XX w., a także akcje przesiedleńcze. $\mathrm{Na}$ jej strukturę etniczno-narodową i wyznaniową znaczący wpływ wywierała natomiast działalność stronnictw narodowych identyfikujących Łemków z większymi wspólnotami zwłaszcza tych, które odwoływały się do wspólnego, wschodniego kręgu kulturowego. Konflikt między ugrupowaniami ukraińskim i starorusko-rusofilskim prowadził wśród Łemków do podziałów. W wyniku wzmożonej ukrainizacji część grupy uznawała się za Ukraińców, a część za Rusinów. Do dezintegracji ludności łemkowskiej prowadziła także polityka państwa polskiego, które w dwudziestoleciu międzywojennym dążyło do ich asymilacji państwowej, a następnie narodowej. W 1900 r. omawiane terytorium zamieszkiwało 21890 Łemków, w tym 21661 wyznania greckokatolickiego. W 1921 r. liczba grekokatolików wynosiła tu 20629 osób, z czego 18897 deklarowało narodowość rusińską. Znaczny spadek populacji widoczny jest w nielicznych miejscowościach, w których Łemkowie nie przekraczali 30 proc. mieszkańców. Może to świadczyć o migracjach ludności, jak również o stopniowej polonizacji. W 1931 r. na badanym obszarze mieszkały 24 tys. Łemków. Wzrost liczby ludności prawosławnej (3647 osób) należy tłumaczyć częstym dokonywaniem konwersji z grekokatolicyzmu, do czego doprowadziła rywalizacja między ugrupowaniami rusofilskim i ukraińskim. Dwudziestolecie międzywojenne to jednak okres ogólnego wzrostu zaludnienia badanego obszaru: między 1921 a 1931 r. przybyło na nim ok. 18 proc. ludności, a do 1939 - kolejne 12 proc. Największe zmiany w strukturze populacji przyniosły przesiedlenia, zwłaszcza powojenne. W latach 1945-1947 z powiatu nowosądeckiego deportowano 
ok. 97 proc. Łemków, co oznaczało zupełne zniszczenie integralności kulturowo-społecznej Łemkowszczyzny. Ludność rozproszona na terenie sowieckiej Ukrainy i ziem poniemieckich $\mathrm{w}$ Polsce pozbawiona została wspólnoty, a duża część Łemków uległa asymilacji. W wyniku zniszczenia centrów kulturalnych i religijnych Łemkowszczyzna jako ojczyzna etniczna ludności łemkowskiej przestała istnieć.

\section{Bibliografia}

\section{Dokumenty publikowane}

Akcja „Wista”. Dokumenty i materiaty, oprac. E. Misiło, Warszawa 2013.

Drugi powszechny spis ludności z dn. 9 XII 1931 r. Mieszkania i gospodarstwa domowe. Ludność. Stosunki zawodowe. Województwo Krakowskie bez miasta Krakowa, red. E. Szturm de Sztrem i in., Warszawa 1938 (Statystyka Polski. Seria C, 88).

Gemeindelexikon der im Reichsrate vertretenen Königreiche und Länder, Bd. 12: Galizien, Wien 1907.

Repatriacja czy deportacja. Przesiedlenie Ukrainców z Polski do USRR. Dokumenty, t. 1, red. E. Misiło, Warszawa 1996.

Mapy

Moklak J., Łemkowszczyzna w II RP (1929 r.), skala: 1:375 000, w: J. Moklak, Łemkowszczyzna w Drugiej Rzeczpospolitej. Zagadnienia polityczne i wyznaniowe, Kraków 1997.

\section{Literatura}

Akcja „Wista”, red. J. Pisuliński, Warszawa 2003.

Barwiński M., Rozmieszczenie i liczebność Łemków $w$ Polsce na podstawie wyników spisu powszechnego z 2002 roku - uwarunkowania i kontrowersje, w: Eemkowie, Bojkowie, Rusini-historia, wspótczesność, kultura materialna i duchowa, t. 2, red. S. Dudra, Zielona Góra 2007.

Best P., Apostolska Administracja Łemkowszczyzny 1934-1944, w: Polska - Ukraina. Studia z dziejów greckokatolickiej diecezji przemyskiej, t. 4, red. S. Stępień, Przemyśl 1998.

Czajkowski J., Dzieje osadnictwa historycznego na Podkarpaciu i jego odzwierciedlenie w grupach etnicznych, w: Eemkowie w historii i kulturze Karpat, cz. 1, red. J. Czajkowski, Rzeszów 1992.

Czajkowski J., Studia nad Łemkowszczyzna, Sanok 1999.

Czt[onek] K. Dobrowolski przedstawit wtasna prace pt. „Zderzenie kultury rolniczej z pasterska”, „Sprawozdania z Czynności i Posiedzeń PAU”, 5, 1939.
Repatriacja czy deportacja. Przesiedlenie Ukrainców z Polski do USRR. Dokumenty, t. 2, red. E. Misiło, Warszawa 1999.

Skorowidz miejscowości Rzeczypospolitej Polskiej opracowany na podstawie wyników Pierwszego Powszechnego Spisu Ludności z dn. 30 września 1921 r. i innych źródet urzędowych, t. 12: Województwo krakowskie. Śląk Cieszyniski, Warszawa 1925.

Ukraincy w Polsce 1944-1989. Walka o tożsamość (dokumenty i materiaty), oprac. R. Drozd, I. Hałagida, Warszawa 1999.

Кубійович В., Етнографічна карта південнозахідньої України (Галичини), skala: 1:250 000, Вісбаден 1983.

Ровенчак I., Аемківщина, skala: 1:275 000, Аьвів 2002.

Cztowiek i przestrzeń. Profesorowi Adamowi Jelonkowi $w 70$. rocznicę urodzin, red. B. Kortus, Kraków 2001.

Długopolski E., Przyczynek do osadnictwa wotoskiego w Karpatach, Kraków 1916.

Dobrowolski K., Dwa studia nad powstaniem kultury ludowej $w$ Karpatach Zachodnich. Z badań nad zagadnieniem wotoskim w Karpatach Zachodnich, w: Studia Podhalańskie oraz Bibliografia pasterstwa Tatr i Podhala, oprac. W. Antoniewicz, K. Dobrowolski, W.H. Paryski, Wrocław 1970 (Pasterstwo Tatr Polskich i Podhala, 8).

Dobrowolski K., Etniczny aspekt osadnictwa wotoskiego na przedpolu Karpat w Matopolsce i na Rusi Czerwonej (XIV-XV), w: Poczattki sasiedztwa. Pogranicze polsko-rusko-stowackie w średniowieczu. Materiaty z konferencji, red. M. Parczewski, Rzeszów 1996.

Dobrowolski K., Migracje wotoskie na ziemiach polskich, Lwów 1930.

Doc[ent] Z. Stieber przedstawia swoja pracę pt. „Wptyw polski i stowacki na gwary Łemków”, „Sprawozdania z Czynności i Posiedzeń PAU”, 41 (2), 1936, s. 45. 
Drozd R., Powojenne wysiedlenia Eemków polskich w latach 1944-1950, w: Eemkowie, Bojkowie, Rusinihistoria, wspótczesność, kultura materialna i duchowa, [t. 1], red. S. Dudra, Zielona Góra 2007.

Drozd R., Ukraincy w Polsce 1944-1947 - losy, postawy, nastroje, w: Akcja „Wista”, red. J. Pisuliński, Warszawa 2003.

Dubiel-Dmytryszyn S., Łemkowie a ruch rusiński, „Rocznik Ruskiej Bursy”, 2007.

Dubiel-Dmytryszyn S., Rusini-Eemkowie - Ukraincy. W kręgu Rusińskiej tożsamości etnicznej w Karpatach, Krosno 2018.

Duć-Fajfer H., Literatura temkowska $w$ drugiej potowie XIX i na początku XX wieku, Kraków 2001.

Dudra S., Akcja , Wista” na Eemkowszczyźnie, „,Rocznik Sądecki”, 26, 1998.

Dudra S., Integracyjna i kulturotwórcza rola Cerkwi $w$ życiu prawostawnych Łemków, w: Łemkowie, red. B. Machul-Telus, Warszawa 2013.

Dudra S., Eemkowie. Deportacje i osadnictwo ludności temkowskiej na środkowym Nadodrzu w latach 1947-1960, Głogów 1998.

Dudra S., Łemkowie na środkowym Nadodrzu (19471956), „Studia Zachodnie”, 4, 1999.

Dudra S., Eemkowie wobec przemian politycznych 1956 roku w Polsce, w: Eemkowie, Bojkowie, Rusini- historia, wspótczesność, kultura materialna i duchowa, [t. 1], red. S. Dudra, Zielona Góra 2007.

Dudra S., Poza mata ojczyzna. Eemkowie na Ziemi Lubuskiej, Wrocław 2008.

Dudra S., Żcie religijne Łemków wyznania prawostawnego na ziemiach zachodniej Polski po akcji "Wista”, „Płaj”, 28, 2004.

Fastnacht A., Osadnictwo ziemi sanockiej w latach 1340-1650, Wrocław 1962.

Horbal B., Dziatalność polityczna Łemków na Łemkowszczyźnie 1918-1921, Wrocław 1997.

Jawor G., Osady prawa wotoskiego i ich mieszkańcy na Rusi Czerwonej w późnym średniowieczu, Lublin 2004.

Krasowski I., Problem autochtonizmu Rusinów w Beskidzie Niskim, w: Eemkowie w historii i kulturze Karpat, cz. 1, red. J. Czajkowski, Rzeszów 1992.

Krochmal A., Stosunki między grekokatolikami i prawostawnymi na Łemkowszczyźnie w latach 1926-1939, w: Łemkowie $w$ historii $i$ kulturze Karpat, cz. 1, red. J. Czajkowski, Rzeszów 1992.

Kwiek J., Przesiedlenie ludności temkowskiej z województwa krakowskiego na Ukrainę (1945-1946), „Studia Historyczne”, 2, 1998.

Kwiek J., Żydzi, Eemkowie, Stowacy w województwie krakowskim w latach 1945-1949/50, Kraków 2002.

Kwilecki A., Aktualne zagadnienia etniczne Łemków w Polsce, „Etnografia Polska”, 12, 1968.

Kwilecki A., Fragmenty najnowszej historii Łemków, „Rocznik Sądecki”, 8, 1967.
Kwilecki A., Fragmenty najnowszej historii Łemków ze szczególnym uwzględnieniem Łemków Sądeckich, Warszawa 1970.

Kwilecki A., Liczebność i rozmieszczenie grup mniejszości narodowych na Ziemiach Zachodnich, „Przegląd Zachodni", 4, 1964.

Kwilecki A., Łemkowie na Ziemi Lubuskiej, „Nadodrze", 5, 1966.

Kwilecki A., Łemkowie. Zagadnienie migracji i asymilacji, Warszawa 1974.

Kwilecki A., Problemy socjologiczne Łemków na Ziemiach Zachodnich. Uwagi teoretyczne i terminologiczne, „Kultura i Społeczeństwo”, 3, 1966.

Kwilecki A., Wspótżycie z ludnością polską i przemiany kulturalne w grupie Łemków, „Etnografia Polska”, 14, 1970.

Kwilecki A., $Z$ zagadnień historycznych $i$ etnicznych dawnej Łemkowszczyzny, „Lud”, 53, 1969.

Kwilecki A., Zagadnienia stabilizacji Łemków na Ziemiach Zachodnich, „Przegląd Zachodni”, 6, 1966.

Lewandowska M., Administracja Apostolska Eemkowszczyzny, „Płaj”, 27, 2003.

Łemkowie, Bojkowie, Rusini - historia, wspótczesność, kultura materialna i duchowa, [t. 1], red. S. Dudra, Zielona Góra 2007.

Eemkowie, Bojkowie, Rusini - historia, wspótczesność, kultura materialna i duchowa, t. 2, red. S. Dudra, Zielona Góra 2009.

Łemkowie i temkoznawstwo w Polsce, red. A.A. Zięba, Kraków 1997 (Prace Komisji Wschodnioeuropejskiej Polskiej Akademii Umiejętności, 5).

Eemkowie $w$ historii $i$ kulturze Karpat, cz. 1, red. J. Czajkowski, Rzeszów 1992.

Michna E., Kwestie etniczno-narodowościowe na pograniczu Stowiańszczyzny Wschodniej i Zachodniej. Ruch rusiński na Stowacji, Ukrainie i w Polsce, Kraków 2004.

Michna E., Łemkowie, grupa etniczna czy naród?, Kraków 1995.

Mironowicz E., Polityka wtadz Polski Ludowej wobec Ukrainców w latach 1944-1947, w: Akcja ,Wista”, red. J. Pisuliński, Warszawa 2003.

Misiak M., Eemkowie. W kręgu badań nad mniejszościami etnolingwistycznymi w Europie, Wrocław 2006.

Moklak J., Łemkowszczyzna w Drugiej Rzeczpospolitej. Zagadnienia polityczne i wyznaniowe, Kraków 1997.

Motyka G., Ukraińska Powstańcza Armia a akcja ,Wista”, w: Akcja ,Wista”, red. J. Pisuliński, Warszawa 2003.

Nabywaniec S., Łemkowszczyzna w świetle badań i opinii, „Resovia Sacra. Studia Teologiczno-Filozoficzne Diecezji Rzeszowskiej”, 2, 1995.

Nalepa J., Eemkowie, Wotosi i Biali Chorwaci. Uwagi dotyczace kwestii genezy osadnictwa ruskiego na polskim Podkarpaciu, „Acta Archaeologica Carpathica”, 24, 1997-1998. 
Nowakowski K., Apostolska Administracja Łemkowszczyzny w latach 1939-1947, w: Polska - Ukraina. 1000 lat sasiedztwa. Studia z dziejów greckokatolickiej diecezji przemyskiej, t. 3, red. S. Stępień, Przemyśl 1996.

Nowakowski K., Sytuacja polityczna na Eemkowszczyźnie, w: Eemkowie w historii i kulturze Karpat, cz. 1, red. J. Czajkowski, Rzeszów 1992.

Olejnik L., Problem ukrainski w polityce narodowościowej państwa polskiego w latach 1944-1957, w: Polska i Ukraina po II wojnie światowej, red. W. Bonusiak, Rzeszów 1998.

Parczewski M., Geneza Łemkowszczyzny w świetle wyników badań archeologicznych, w: Łemkowie $w$ historii i kulturze Karpat, cz. 1, red. J. Czajkowski, Rzeszów 1992.

Parczewski M., Początki ksztattowania się polsko-ruskiej rubieży etnicznej w Karpatach, Kraków 1991.

Pieradzka K., Na szlakach Łemkowszczyzny, Kraków 1939.

Pisuliński J., Akcja Specjalna „Wista”, Rzeszów 2017.

Pisuliński J., Polityka wtadz wobec spoteczności ukraińskiej w latach 1944-1956, „Pamięć i Sprawiedliwość", 3/2 (6), 2004.

Pisuliński J., Przesiedlenie ludności ukraińskiej z Polski do USRR w latach 1944-1947, Rzeszów 2009.

Początki sasiedztwa. Pogranicze polsko-rusko-stowackie w'redniowieczu. Materiaty z konferencji, red. M. Parczewski, Rzeszów 1996.

Polska i Ukraina po II wojnie światowej, red. W. Bonusiak, Rzeszów 1998.

Polska - Ukraina. 1000 lat sasiedztwa. Studia z dziejów greckokatolickiej diecezji przemyskiej, t. 3, red. S. Stępień, Przemyśl 1996.

Pudło K., Dzieje Łemków po drugiej wojnie światowej, w: Łemkowie w historii i kulturze Karpat, cz. 1, red. J. Czajkowski, Rzeszów 1992.

Pudło K., Eemkowie na Dolnym Ślasku (1947-1982), „Rocznik Dolnośląski”, 9, 1985.

Pudło K., Łemkowie. Proces wrastania $w$ środowisko Dolnego Ślaska 1947-1985, „Prace i Materiały Etnograficzne", 28, 1987.

Reinfuss R., Etnograficzne granice Eemkowszczyzny. Próba wytyczenia granicy Eemkowszczyzny na podstawie zasieggu temkowskiego stroju, „Ziemia. Ilustrowany miesięcznik krajoznawczy”, 10/11, 1936.

Reinfuss R., Łemkowie jako grupa etnograficzna, Sanok 1998.

Soja M., Zmiany zaludnienia Łemkowszczyzny $w$ latach 1869-1998, w: Cztowiek i przestrzeń. Profesorowi Adamowi Jelonkowi $w 70$. rocznice urodzin, red. B. Kortus, Kraków 2001.
Stadnicki A., O wsiach tzw. wotoskich na pótnocnym stoku Karpat, Lwów 1848.

Stępień S., Organizacja i struktura terytorialna greckokatolickiej diecezji przemyskiej w latach 1918-1939, w: Polska - Ukraina. 1000 lat sasiedztwa. Studia z dziejów greckokatolickiej diecezji przemyskiej, t. 3, red. S. Stępień, Przemyśl 1996.

Struminśki B., O pochodzeniu Łemków z punktu widzenia językoznawstwa, „Magury”, 91, 1992.

Studia Podhalańskie oraz Bibliografia pasterstwa Tatr i Podhala, oprac. W. Antoniewicz, K. Dobrowolski, W.H. Paryski, Wrocław 1970 (Pasterstwo Tatr Polskich i Podhala, 8).

Szanter Z., Jeszcze o osadnictwie zza potudniowej granicy $w$ Beskidzie Niskim i Sądeckim, w: Łemkowie i temkoznawstwo w Polsce, red. A.A. Zięba, Kraków 1997 (Prace Komisji Wschodnioeuropejskiej Polskiej Akademii Umiejętności, 5).

Tomaszewski J., Landau Z., Spoteczeństwo Drugiej Rzeczpospolitej (uwagi polemiczne), „Przegląd Historyczny", 61 (2), 1970.

Torzecki R., Kwestia ukrainska w polityce III Rzeszy (1933-1945), Warszawa 1972.

Trzeszczyńska P., Łemkowszczyzna zapamiętana. Opowieści o przesztości i przestrzeni, Kraków 2013.

Wilk A., Eemkowie. Między integracją a rozproszeniem 1918-1989, Warszawa 2019.

Wyniki Narodowego Spisu Powszechnego Ludności i Mieszkań 2002 (https://stat.gov.pl/cps/rde/xbcr/ gus/raport_z_wynikow_nsp_ludnosci_i_mieszkan_2002.pdf, dostęp: 18 września 2020).

Wyniki Narodowego Spisu Powszechnego Ludności i Mieszkań 2002 w zakresie deklarowanej narodowości oraz języka używanego $w$ domu, „Główny Urząd Statystyczny” (https://stat.gov.pl/spisy-powszechne/narodowe-spisy-powszechne/narodowy-spis-powszechny-2002/wyniki-narodowego-spisupowszechnego-2002-narodowosci-oraz-jezyka/, dostęp: 18 września 2020).

Zięba A.A., Wokót sporów o etnogenezę Łemków, w: Eemkowie, red. B. Machul-Telus, Warszawa 2013.

Грушевський М., Iсторія України-Руси, т. 1, Аьвів 1904.

Зілинський I., Питання про лемківсько-бойківську мовну границю, „Lud Słowiański”, 4 (1), 1938.

Кубійович В., Етнічні групи південносхідньої Украӥни (Галичини) на 1.1.1939, Вісбаден 1983 (http://diasporiana.org.ua/wp-content/uploads/books/10893/ file.pdf, dostęp: 18 września 2020).

Кубійович В., Украйні в Генеральній Губернії 1939 1941 - Iсторія Украӥнського Центрального Коміmету, Чікаго 1975. 


\section{Changes in the distribution and structure of the Lemko population in Nowy Sącz County in the years 1900-1947}

\section{Summary}

The present paper seeks to develop an overview of the demographic changes among the Lemko population which took place in the first half of the $19^{\text {th }}$ century in the territory of Nowy Sacz County, whose south-eastern areas formed part of the Lemkivshchyna ethnographic region.

The object of research were localities inhabited by the Lemkos in the period between 1900 and 1947, with the latter year marking the conclusion of the displacement campaign carried out as part of Operation Vistula. Data on population size according to national-ethnic criteria have been drawn from censuses carried out in the years 1900-1931 (information concerning this period also includes data on the linguistic and religious structure of the population) as well as archival documents stored in the State Archives in Kraków, the Archives of Modern Records, and the Archives of the Institute of National Remembrance.
Localities inhabited by the Lemko people were usually ethnically and religiously uniform, with the Lemkos constituting the vast majority of the population $(95-100 \%)$ in $70 \%$ of localities inhabited by this ethnic group in Nowy Sącz County. In the years 1900-1945, the structure of the Lemko population underwent changes resulting from political and economic processes, especially in the period of the two world wars. The greatest changes in the population structure took place in the years 1945-1947, when the Lemkos were displaced en masse to the territory of the Ukrainian Soviet Socialist Republic and resettled to post-German territories as part of Operation Vistula. The outcome of archival research carried out by the author has made it possible to attempt an analysis of the changes taking place in the structure of the Lemko people with regard to their political causes.

dr Anna Wilk - historyk, autorka książki Łemkowie. Między integracją a rozproszeniem (2019). Jej zainteresowania naukowe skupiają się na historii mniejszości narodowych z uwzględnieniem zagadnień tożsamościowych oraz na polityce narodowościowej władz RP. Publikowała m.in. w „Pamięci i Sprawiedliwości” oraz „Aparacie Represji w Polsce Ludowej 1944-1989"

(annawilk1986@gmail.com)

Anna Wilk, PhD - historian, author of the book Łemkowie. Między integracją a rozproszeniem (2019). Her research interests focus on the history of national minorities with particular emphasis on the issue of identity, as well as the ethnic policy of the authorities of the Republic of Poland. Her papers have been published in such journals as "Pamięć i Sprawiedliwość" or "Aparat Represji w Polsce Ludowej 1944-1989"

(annawilk1986@gmail.com) 